\title{
MEASUREMENTS OF AUDITORY ORGANS OF VERTEBRATES
}

\author{
By \\ O. FUKUDA \\ From the Department of Oto-Rhino-Laryngology, Faculty of Medicine, University of Tokyo \\ (Director: Prof. I Kirikae)
}

The author measured the diameter, the length and the capacity of external auditory meatus and middle ear cavity in 34 different species of vertebrates including 2 amphibians, 4 reptiles, 6 birds, and 22 mammals, to study the mutual relationship of each measurement and also studied the morphology of the middle ear cavities.

The conclusions were as follows :-

1). The length of the external auditory meatus was always in proportion to the size of the skulls, but not to the breadth. The larger animals had longer meatus. The ratio of the length to breadth of meatus was 11.4 in ox, 13.7 in pig, but in small animals like bat or rat, was nearly 1.0 .

In animals which behave in water, for example, otter, sea-lion and fur-seal, the ratios were remarkably large. The partially closed meatus observed in whale was an extreme case.

2). The external auditory meatus is essential for fine perception of air conduction sound. Moreover, the resonance effect of the meatus which is determined by the length of it may profit the hearing acuity of the animal, when awared of the close relationship between tbe resonance effect and animal's cry.

3). The capacity of tympanic cavity was always larger than those of external meatus, and the ratio dividing the former by the latter was very much constant in each mammal, for example, 3.0 $\sim 3.4$ in dogs. and $3.7 \sim 4.1$ in cats.

4). In general, the capacity of the tympanic cavity was proportional to the size of the head, mainly due to the capacity of the tympanic bulla. On the other hand, the mesotympanum containing the tympanic membrane, ossicles and windows showed a little variation.

I have observed also this tendency among the different mammals. The ratio of tympanic cavity per $\mathrm{lmm}^{2}$ of ear drum was 4 in rat, 6 in mole and 435 in ox.

5). The tympanic cavity of bird was uniform in shape as well as external meatus, except some variation in shape and size of air cells fully developed in the skull.

6). The form of accessory air spaces of vertebrates were classified into several types according to the "order" or "family", such as single bulla with or without bony septum (rodentia, chiroptera, some uugulates and cetacea), and cellular structure developed in the bulla (ox, pig and horse), in the mastoid process (some primates), or in the basis of the skull (insectivora).

7). But certain irregularities of the structures of the auditory organs were noted, because of the adaptation to the circumstances. For example, Barary sheep, classified in bovidae, had a single bulla and large epitympanum with large Schrapnell's membrane as seen in cervidae.

8). Accessory air spaces are thought to have significance in four points, that is, making the tympanic membrane easily vibrate by the low frequency sound waves, reducing the weight of the skull, and the effect of reservoir action and acoustic dissipation. The resonance or insullation effect are doubtful.

9). The size of the air sinuses in the skull has a tendency to change according to the size of the skull. Therefore we must consider the relation of the both when the air sinuses are discussed. 


\title{
諸種脊椎動物聴器の計測的研究
}

\author{
第 1 編 外耳道特よび中耳腔
}

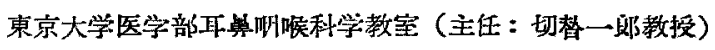

福思紧紧

目次

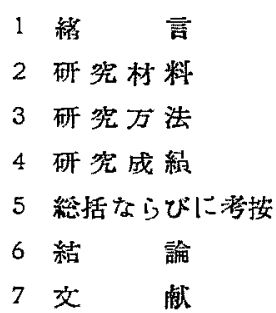

1. 緒言

種々の動物の聴器を形態学旳に観察して比較検討する ことは人問の德覚機構を解明するのに極めて重要な手が

\りとなる. 隹椎動物門のうちで, 魚類はその生活環境 から当然気尊音を聴く装置がなく，中耳は陸上生活をす る両悽類以上に見られるが，その形態はおのおの上動物 の生活環境のちがいに応じてそれでれ特徽ある变化をし めしている. これらについて Retzıus, Eschweller, Beyer, Chauveau, Syk, Freund, Butschl, Burlet, Brock, Echert-Mobıus. Wolf, 柴田, Secondi, Tumarkınなどの各種㕠椎動物聴器の比較解剖学的研究の業 續がある。

しかし聴器の計測についての報告は Freund, Secondi, 吉田, Whittle, Wever-Lawrence-Smith などが

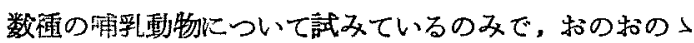
計則值て比較検訂した精細な報告はいまだみられない。

私は两椿類以上の高等脊椎動物の德器について，その 外耳および中耳の構成部分を計測して比較唡討すると共

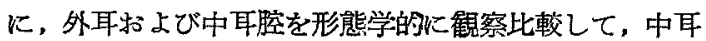
副膑の意義について若干の知見を得たのてこつに報告す る.

\section{2. 研究材料}

1) 両 櫙 類

無 尾 目

ひきがえる Bufo vulgaris

らしか゚える Rana catesbiana

II)爬虫類

有 鳞 目
やもり Gecko japonicus

かめれおん Chameleon chameleon

唵目

いしがぬ Clemmys japonica

すつぽん Amyda trionyx

III) 鳥類

にわとり Gallus gallus domesticus

しちめえちよう Meleagris gallopavo

はと目

はと Columba livia

がんか子目

まがも Anus platyrhcha

㵩雀 目

つぐみ Turdus naumann

和 5 志目

せきせいっえこ Melopsittacus undulatus

V) 哺乳類

欠齿 目

らさぎ Oryctolagus cuniculus

りす Sciurus lis

くまねずみ Rattus rattus

むるもつと Cavia cobaya

食虫目

ஆぐら Mogera wogura

翼手目

いえこ5もり Pipistrellus abramus

霊 長

にほんざる Pithecus fuscatus

食肉目

Wぬ Cants familiaris

L) Felis leo

标こ Felis domestica

ひぐま Ursus arctos

かわらそ Lutra lutra

あしか, Zalophus gillespı.

特っとせい Callorhınus alascanus 
偶 蹄 目

Sた Sus scrofa

5 L Bos taurus

ひつじ Ovis arres

かむしか Capricornis crispus

きよん Muntıacus reevesı

ばーばりひつじ Ammotragus lerıvıa

鯨目

ながすくじら（胎生5カ月）

Balaenoptera physalus

奇 蹄 目

$\zeta ま$ Equus caballus

\section{3. 研究方法}

死後なるへく早いらちにとりだした側頭骨を $10 \%$ ホ ルマリン溶液で固定して用いた・各部位の計測值を比較 するため，また動物によつては多数入手てきないものも あるので，一個の聴器てすべての計測を行うよらにし た.

長さの湘定には直接ギスをあて，小さな秋料につい てはミクロメーターを顕微鏡に装着して行つた・このさ いギスは誤差が $0.1 \mathrm{~mm}$ 以内にとら゙をるよう練習し同 一部位を 5〜7 回測定して同一檤の多い6のを採つた。 外耳道大口部の径は最大经と最小径を，また外耳道の長

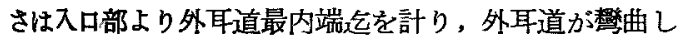
ているものについては絹糸をはりつけその長さを則定し た

体積の湘定には鋳型を作る予備実験を行つたが，バラ フインでは完全な鋳型を作ることはその材料の性質上難 しく、リポウイッッ合金などは加熱を要し取り出す時他 部を損賃し易く，合成樹脂も同様な欠卢の他に体積变動 が10\%内外あるため，本実験にはメスビペットて補正

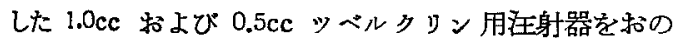
特の3本ずっ用意して特き，湘定部位の水分を榴紙で充 分吸収し乾燥させないて，注入したこ水の量より容積を承 める方法を同一標本について5 回宛扎こなつて最大值と 最小值を除いたすの今平均值をとつたいるとるにつ いてこの方法とリボウイッッ合金を使用して計瀴した 体樻を比較するとその證差は士0.5\% 以内茎であつた。

このさい耳管などは軟亭でらさいで水分の流失をらせ ぐようにしたが，鳥の中耳腔は頭蓋の蜂巣と広く交通し ているので,メタクリル酸エステル樹脂の鋳型を作つて 㓩定した・またふたは蜂兼が細かいので水を满した場合

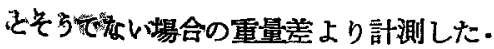

4. 研究 成續

1. 外耳道の入口部の径, 長さ, その比 (Table 1,2) 外耳道の長さは頭蓋の大きさに相応していて，偶蹄頌 ては長く，小動物ては耳介は大きいが䄪耳道は著しく短 い. 食肉類のなかて电肢脚類では外耳道が稫く，鯺脚類 ては長い.鳥類の外耳道は哺乳類のそれと比較すると短 くない.

それに対し入口部の堡は頭蓋の大小と㟻べてそれ活ど 著明な差はなく，特に偶蹄類，奇蹄類ては非常に紏く見 える・食肉類のらちては肢脚類が太く䦃脚類か細い.島 類は一般に太い。くじらの外耳遖は外側へいくにつれて あたかる铅筆のキャップ状に細くなり盲管となつて終る

Table 1 外巫道の言歫值

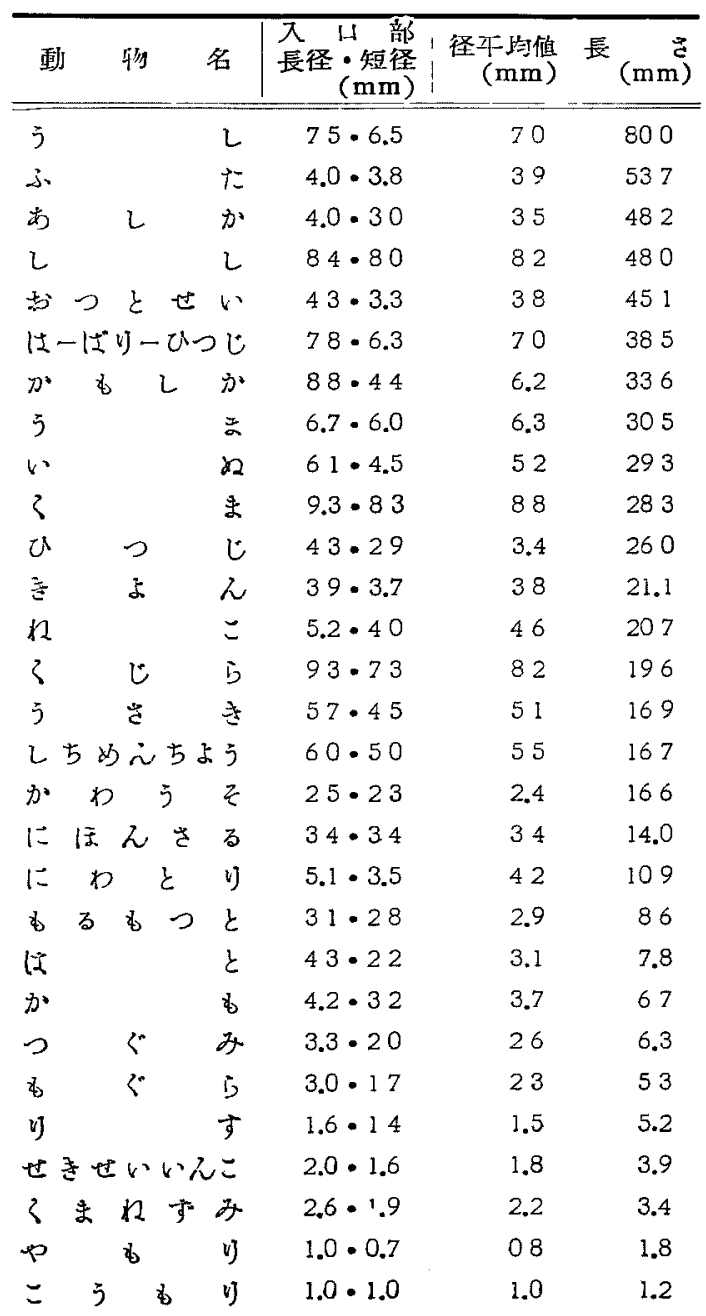


Table 2 外耳道の長さと入口部征の比

\begin{tabular}{|c|c|c|c|c|}
\hline 種 & & 物 & 名 & "長さ/径 \\
\hline o & & L & מ & 13.8 \\
\hline 3 & & & $t$ & 13.7 \\
\hline jo & $\supset$ & と & $w^{2}$ & 12.0 \\
\hline 5 & & & L & 11.4 \\
\hline 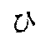 & & $\supset$ & じ & 7.6 \\
\hline$\not x$ & D & $j$ & $z$ & 6.9 \\
\hline L & & & L & 5.9 \\
\hline 4 & & & $d$ & 5.6 \\
\hline$s$ & & $\downarrow$ & $\dot{L}$ & 5.5 \\
\hline \multicolumn{4}{|c|}{ ばーばりーひつじ } & 5.5 \\
\hline 市 & 8 & 2 & $y j^{2}$ & 5.4 \\
\hline$う$ & & & ま & 4.9 \\
\hline$k$ & & & $こ$ & 45 \\
\hline 1. & ほ & $\sim$ 巳゙ & る & 4.1 \\
\hline 》 & & & $す$ & 3.5 \\
\hline 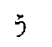 & & $\ddot{c}$ & + & 3.3 \\
\hline 3 & & & ま & 3.2 \\
\hline 2 & 585 & 255 & 5 & 3.0 \\
\hline \& & る & \& 0 & $\zeta$ & 3.0 \\
\hline $1-$ & $D$ & $\varepsilon$ & b & 2.6 \\
\hline p & & $\&$ & v & 2.6 \\
\hline は & & & $z$ & 2.5 \\
\hline o & & $<$ & み & 2.4 \\
\hline 3 & & $\dot{L}$ & 5 & 2.4 \\
\hline है & & ぐ & 5 & 2.3 \\
\hline せ & & 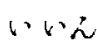 & $\varepsilon=$ & 2.2 \\
\hline s. & & & 6 & 1.8 \\
\hline$n$ & & j" & み & 1.5 \\
\hline$こ$ & $j$ & छ & 门 & 12 \\
\hline
\end{tabular}

のて，鼓膜輪部の径を測定した。

外耳道の長さとその入口部径の平均值との比を較べる と大きい動物程この比率が大てある. それは頭の大きい 動物程外耳道を洲長く，小さい動物程外耳道は太く短い 傾向があることを示している・すなわちうしやふたの外 耳道は極端に長いが，こうもり，ねずみ，もるもつとな どは大きい耳介を有しているのにかつわらず外耳道自体 は極めて短い：また水中に活動する哺乳類あしか，おつ とせい，かわうそては比率が大てあって細長い.くじら は外耳道の一部が閉鎖しているため比率は小てある. 食 肉類の肢脚類と霊長類ては比が小さい．鳥類も比が小さ いが㗘乳類との間に著明な羑はみられなからた ii. 誃耳道の体積 (Table 3) 食肉類および鳥類が比較的大きい值を示している。

Table 3 外耳道・聑腔の体䅡

\begin{tabular}{|c|c|c|c|c|c|c|}
\hline \multicolumn{2}{|c|}{ 動 } & 45 & 名 & & $\begin{array}{r}\text { 外耳道体䅡 } \\
(\mathrm{mI}) \\
\end{array}$ & 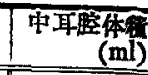 \\
\hline \multicolumn{3}{|l|}{5} & L & & 3.60 & 227 \\
\hline \multicolumn{3}{|l|}{ L } & L & & 1.28 & 13.2 \\
\hline \multicolumn{3}{|l|}{3} & ந & & 022 & 7.5 \\
\hline ఫ & 2 & I & 2 & & $\rightarrow$ & 3.95 \\
\hline נ* & क & L & か & & 0.75 & 2.95 \\
\hline \multicolumn{4}{|c|}{ ばーばりーひつし } & & 060 & 2.08 \\
\hline \multicolumn{3}{|c|}{3} & $ま$ & & 0.89 & 1.98 \\
\hline \multicolumn{3}{|l|}{$j$} & z & & 0.46 & 164 \\
\hline \multicolumn{3}{|l|}{35} & $T$ & & 0.68 & $1.60^{\circ}$ \\
\hline \multicolumn{3}{|l|}{$w$} & $a$ & & 0.40 & 1.20 \\
\hline \multicolumn{2}{|l|}{ ㄴ. } & $\Sigma$ & 2 & & 016 & 1.14 \\
\hline \multicolumn{2}{|l|}{$u$} & D & $\dot{E}$ & & 0.35 & 1.08 \\
\hline \multicolumn{2}{|l|}{12} & & $\Xi$ & & 0.25 & 0.98 \\
\hline \multicolumn{2}{|l|}{5} & が & る & & - & 0.80 \\
\hline \multicolumn{2}{|l|}{$\vec{c}$} & & る & & 0.09 & 0.46 \\
\hline \multicolumn{2}{|c|}{$\infty$} & ᄂ & $\infty$ & & 031 & 0.40 \\
\hline \multicolumn{5}{|c|}{ しちめんちよう } & 0.18 & 0.40 \\
\hline$お$ & $\supset$ & とせ & $w$ & & 0.32 & 0.32 \\
\hline \multirow{2}{*}{ に } & x & z & v) & & 0.15 & 0.30 \\
\hline \multirow{2}{*}{\multicolumn{2}{|c|}{$\begin{array}{l}j \\
\text { I }\end{array}$}} & $\ddot{c}$ & * & & 0.22 & 0.28 \\
\hline & & & $\varepsilon$ & & 0.10 & 0.22 \\
\hline 8 & る & 80 & $\xi$ & I & 0.04 & $0.2 \mathrm{~N}$ \\
\hline \multicolumn{2}{|c|}{ מ } & & b & & 0.09 & 0.20 \\
\hline か & D & 5 & $\varepsilon$ & & 0.06 & 0.17 \\
\hline \multirow{2}{*}{$\begin{array}{l}w \\
v\end{array}$} & 2 & b゙ & $\phi$ & & - & 0.15 \\
\hline & & & $す$ & & 003 & 0.11 \\
\hline 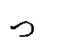 & & ぐ & み & & 0.06 & 0.14 \\
\hline 8 & & ぐ & 5 & 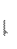 & 003 & 0,08 \\
\hline \multirow{2}{*}{ 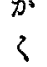 } & $\infty$ & れら & 2 & & - & 0.05 \\
\hline & $ま$ & Rす & み & & $<0.01$ & 0.02 \\
\hline tis & & & ま & & - & 0.02 \\
\hline$p$ & & 8 & y & & - & 0.02 \\
\hline$=$ & j & b & $y$ & & $<0.01$ & $<0.0 \mathrm{r}$ \\
\hline$t$ & ? & wい2 & & & $<001$ & $<0.01$ \\
\hline
\end{tabular}

111. 中耳帮の体積 (Table 3)

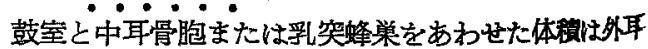
道と同様に碩蓋の大きさに暞応して变化するが，そのな

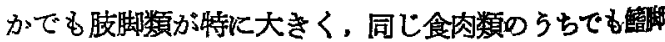
類は小さい.くじらの中耳腔には胎生期のための扬 質が允满していたのでこれを除いて測つた・鳥積の中耳 


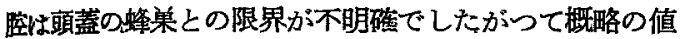
でり，から哺乳類の副腔に相当するすのか除然されて いるのでこれを比較するのは適当てないが，かなり大き い値を示している。

1v. 中耳腔と然耳道の体皘の比 (Table 4)

Table 4.中耳腔と外耳道の体積比

\begin{tabular}{|c|c|c|c|c|}
\hline 動 & & $f / 9$ & 名 & 中耳腟/外耳道 \\
\hline 3 & & \multirow[t]{2}{*}{ E } & ந & 340 \\
\hline ᄂ & & & L & 10.3 \\
\hline$\xi$ & \multirow{2}{*}{\multicolumn{2}{|c|}{ s. }} & $i$ & 7.1 \\
\hline$j$ & & & ᄂ & 6.3 \\
\hline b & के & b $=$ & $\varepsilon$ & 5.2 \\
\hline$E 1$ & 玉 & 2 & 3 & 5.1 \\
\hline か & क & L & \multirow{2}{*}{$\begin{array}{l}\text { } \\
=\end{array}$} & 3.9 \\
\hline \multicolumn{2}{|l|}{11} & & & 3.9 \\
\hline \multicolumn{3}{|l|}{ v] } & す & 3.7 \\
\hline \multicolumn{3}{|l|}{5} & ま & 3.6 \\
\hline \multicolumn{4}{|c|}{ ボーばりーひっし } & 3.5 \\
\hline$u$ & \multicolumn{2}{|c|}{$\supset$} & $\mathrm{E}$ & 3.1 \\
\hline \multicolumn{3}{|l|}{$\checkmark$} & $x$ & 3.0 \\
\hline$s^{2}$ & D & \multirow{2}{*}{$x^{j}$} & $z$ & 28 \\
\hline 4 & & & 5 & 2.7 \\
\hline 3 & & ぐ & た & 2.4 \\
\hline$ひ$ & & 5 & ま & 2.2 \\
\hline \multicolumn{3}{|c|}{ か } & क & 2.2 \\
\hline \multicolumn{4}{|c|}{ しちめえちょう } & 22 \\
\hline \multicolumn{3}{|c|}{ is } & $\varepsilon$ & 2.2 \\
\hline \multirow{2}{*}{\multicolumn{3}{|c|}{$-\infty z$}} & ij & 2.0 \\
\hline & & & み & $>2.0$ \\
\hline$\supset$ & & $\begin{array}{l}9 \\
\zeta ゙\end{array}$ & み & 1.8 \\
\hline$j$ & & $\vec{c}$ & 我 & 1.3 \\
\hline क) & & ᄂ & か & 1.3 \\
\hline $5=$ & 0 & $\varepsilon$ & $w$ & 10 \\
\hline
\end{tabular}

中耳腔体積と外耳道体積との比率は分類学的にもまた は䫓蓋の大小によっても差は認められないが，2〜4の 間の值を示すむのが多いことは注目にあたいする。そし て中耳㤏体積は必ず外耳道のそれより大きい。

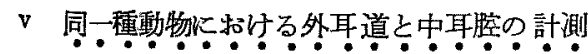
(Table 5,6 )

同一種動物のうちて，頭の大きさの異るものについて 外耳道と中耳腔の体積の関倸をしらべるため同様な計測 を行つた・被検動物としては体の大きさに大小さまざま のちがいがあつて，中耳骨胞が隔壁によつて中鼓室と境
Table 5. いタの䚵測值

\begin{tabular}{|c|c|c|c|c|c|}
\hline 侧 & 体 $\begin{array}{r}\text { 重 } \\
\mathrm{kg}\end{array}$ & 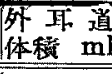 & 体稆 $\mathrm{ml}$ & $\begin{array}{l}\text { 年开 } \\
\text { 外道 }\end{array}$ & 鼓腃輪 $\mathrm{mm}$ \\
\hline 1 & 18 & 0.51 & 1.74 & 3.4 & $9.3 \times 6.9$ \\
\hline 2 & 13 & 0.42 & 1.24 & 3.0 & $9.4 \times 6.5$ \\
\hline 3 & 13 & 0.40 & 1.20 & 3.0 & $9.2 \times 6.6$ \\
\hline 4 & 10 & 0.39 & 1.33 & 3.4 & $89 \times 6.6$ \\
\hline 5 & 9 & 0.28 & 0.94 & 34 & $9.0 \times 6.3$ \\
\hline 6 & 5 & 014 & 0.44 & 3.1 & $92 \times 66$ \\
\hline
\end{tabular}

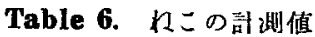

\begin{tabular}{|c|c|c|c|c|c|c|}
\hline 例 & $\begin{array}{r}\text { 体重 } \\
\mathrm{kg}\end{array}$ & $\begin{array}{l}\text { 外正道 } \\
\text { 和 }\end{array}$ & 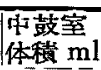 & 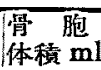 & 中外耳 & 鼓脱輪 mm \\
\hline 1 & 2.5 & 0.25 & $0.2^{4}$ & 0.74 & 3.9 & $8.9 \times 62$ \\
\hline 2 & 1.4 & 0.16 & 0.23 & 043 & 4.1 & $8.5 \times 5.9$ \\
\hline 3 & 1.3 & 0.17 & 0.24 & 0.39 & 3.7 & $8.5 \times 6.0$ \\
\hline 4 & 0.9 & 0.14 & 0.23 & 0.34 & 4.1 & $8.7 \times 6.1$ \\
\hline 5 & 07 & 011 & 0.20 & 0.23 & 40 & $7.9 \times 6.0$ \\
\hline
\end{tabular}

されている動物として選んだ，いぬおよびねこを使用し た.

いぬ (Table 5) では外耳道体積および中耳脘体積は 概して体重に相応して変化するが，その变化の割合はや 〉少いこれは恐らく幼若動物ては成獸にくらべて比較 的頭が大きいためであろ5.中耳腔と外耳道の体積比は 3.0 と 3.4 の間にあり，かなり一定した值をとつている。 それに反し鼓膜輪の大きさはあまり变化せず，また鼓室 小骨の大きさむ㱠んど同じ大きさであることより，頭蓋 の大小の差と外耳道怙よび中耳腔の体積とは相関々係が みられる・さらにいぬの鼓室と中耳骨胞とは不完全な 骨の隔壁によつて境されているが，沶のおの」大きさに ついてみると頭の大きさがちがつても中鼓室の体積には 殆んど差がみられなくて，中耳骨胞の大きさのみに著し い差異がある。

ねこ(Table 6)に执いても全く同样なことがいえる。 中耳腔と外耳道の体積の比は 3.7 4 1 の間にあつて，い ぬよりや」大きい、またねこては中鼓室と中耳骨胞はほ ぶ完全な隔壁によつて境されているか，中鼓室の体積は 注よ゙一定し骨胞の体積のみが頭の大きさがちがうにつれ て著しくちがっている.そしていぬと同栐に鼓室小骨の、 大きさは一定て頭の大きさとは関係がない。

v1. 外耳道の形熋

爬虫頻てはやもりに外耳道がみられる・すなわら眼筒 の後上方て背腹方向にや入扁平な形をした小孔が体表に 垂直にあって肉方に入るにしたか゚つて㹡がつている・外 
耳道の皮䖉は大部分が体表の鱗状皮諴の続きで，下壁は 下顎骨によって支持され，その他は筋組織でとりまかれ ている・骨部は鼓膜の近くに僅か火存在する・

鳥類の外耳道の入口部は羽毛て被われているが，にわ とリ，しちめんちようでは後縁または下緑より発生した 風毛によつて粗に被われるに反し，はと，つぐみ，か も，せきせいいんこなどよく飛翔てきる鳥では泌生した 頭部羽毛に被われて外耳道の所在は判然としない，外耳 道口は常に棈円形て多くはこの長軸が背腹方向にあり， から鼓膜の長軸と平行しているが，かもてはその長軸は 頭尾方向にある・外耳道は全体としてU 型または V 型に尾方に向つて䇣曲しているがその程度は鳥類の種類 比よて善がみられる．せきせいいんこでは外耳道が短

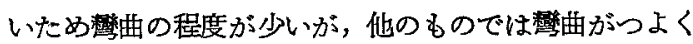
然耳道口より鼓膜を稓うことはできない。しかしかむて は外耳道は腹方に屈曲乙鼓膜が後方に向っているが，外 耳道の屈曲が少いため外耳道口より鼓膜を見ることが可 能てある。

外耳道は原い皮呞に被われ㳄骨はなく，骨部外耳道は 不完全である・前壁には骨部はないが，鼓膜輸前上万に 接して顎開節があり，その下方すなわち前壁には下顎骨 の上䫁突起があつて膨隆し，外耳遺はこれをとり巻くよ らに繁曲している.この膨隆のため外耳道の中間部は最 む狭く扁平である・せきせいいんこでは顎関節が下方に 偏在し，外耳道前上壁は側頭骨比よつて形成されている

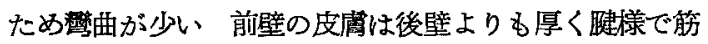
膜および腱が附着し強靯な情造を示している・後壁には 骨部がかなりの大きさに認められる・にわとり，しちめ んちよう，はとの骨部外耳道は半月状て短く，その外方 は側頭骨に附着する愿い腱㥞の膜にとり巻かれててきて いる.この膜は外耳道下壁ては皮膚に移行しているが， 後壁ては皮膚とはあきらか別となつている・つぐみ， かも，せきせいいんこの外耳道後壁は側頭骨鱗部よりな る骨部がかなり広く，その一部は下壁をむ形成し，琏様 の脱は僅かにその足りない部分を被うか，または全く認 わられない。

鳥類の外耳道で特徽あることは最内部すなわち㖕膜に 面する部分が著しく膨大していることで，こういう状態 は㐸に述べる唃乳類の外耳道と対照的である.

哺乳類の外耳道は鳥類のそれ之較べるとほ5゙真直の円 筒形て，成体ては入口部に物いて最も太く鼓膜に近い内 端 (Recessus meatus externus) は極度に狭くなつて いる・特ににほんざ，かもしか，きよん，ばーばりー
ひつじは淁膜と外耳道下壁が殆んと接着するくらい惯 近している・外耳道の走行は一般に下内前方に向ってい る。

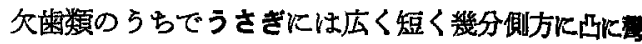
曲した然耳道があつて，その骨部は骨胞によって形成さ れるのみで大部分は軟骨部である あるもつと，特す, ねずみ乱よび翼手類のこうありでは前速の如く玠性大 きいが然耳道自体は極めて短く 2 3mm で大きな鼓暻

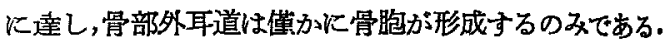

食虫類もぐらには耳年は無く外耳道口は体毛によって 被われ，内部は外方の広い部分之内方のさら飞狭い部分 に分けられるが，前者は耳介属し，後者は真の外耳道 てあると考えられる 骨部は殆んどない。

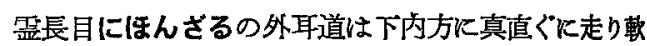
骨部が大部分を占め，競腽附近では非常に扁平となり， 殆んそ溒膜と下壁とが接触するくらいである

食肉類の外耳道は一般に太い円筒形でや〉㑡腹方に凸

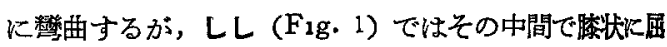
曲するに対し，〈ま，ねこ，いぬではゆるやか炕獤曲す る・かわうそては比較的細く，真直ぐに腹内方に向い，

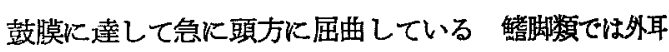
道は細長くほぶその中間て側方に高度の凸蒻曲を示し，

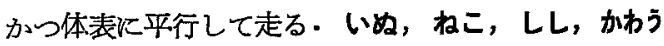
そ，おつとせい，あしかでは中耳骨胞と鱗状骨が短い骨 部外耳道を形成し大部分は軟骨部であるが，くまで路

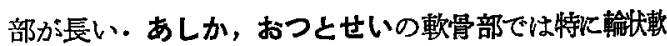
骨が厚く長く発奎している。

偶蹄類のうちでうしとぶたの外耳道は大部分がは心゙同 じ大さの第状の骨部からなり，うしではゆるやが尾背

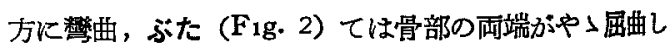
ている・ひつじでも大部分が骨部で紐長く真直ぐでる が，鼓荧と外耳道のなす角が直角に近いため，内端が 「とびロ」のように屈曲している．ばーばりーひつし， かもしか，きよんでは互に類似してや〉広い少しく漏斗 状て 尾背方にや入 凸なゆるやかな禁曲をして骨部が長 く，その上壁を巨大なノュラブネル氏膜が占めることが 著しい特微である・外耳道内端は潹く骨胞内深出し， しかも下壁は鼓膜と殆えど接触する程扁平で㹟い。 奇䟲類うまの外耳道は短く水平でや〉背内方飞延でた 漏斗状で，骨部が大部分を占めている。

くじらは胎生 5 力月のものであるが，まだ外方部拈よ び中間索状部恃全くなく，内方部が鉛筆キャッフ状を呈 している. 
Fig. 3 (1).中耳腔の形態（右側）

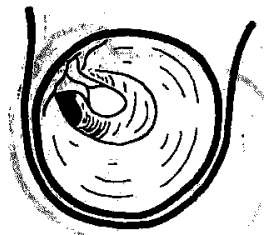

1. ขะがそる

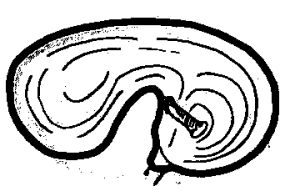

4. い iがか

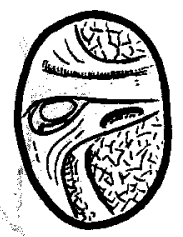

9. $154 k+57$

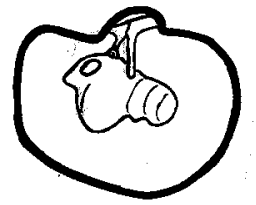

10. $\neq t=\varepsilon$

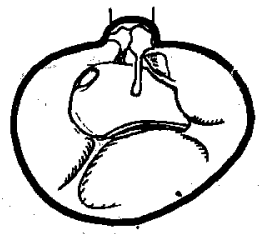

13. ‡

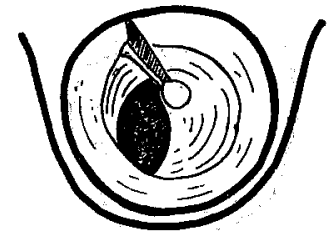

2. iがネる

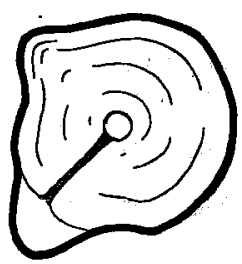

5. $\rfloor_{2} 10^{\circ} h$

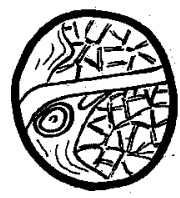

8.tetheshe

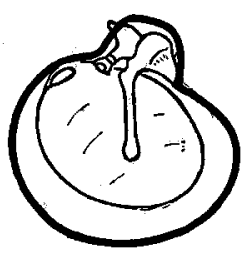

II. $<+\operatorname{tat} 2 x$

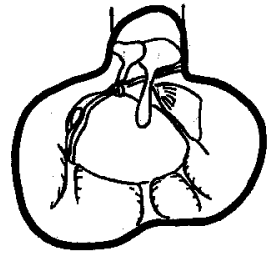

14. 1$)$

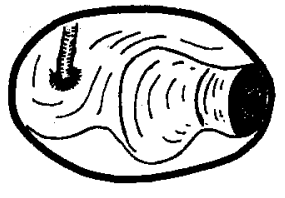

3. $\star \bullet$

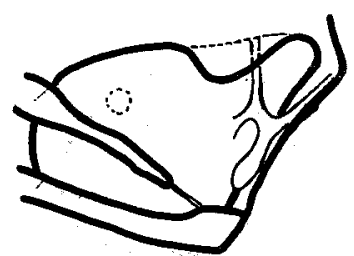

6. かッカ十な

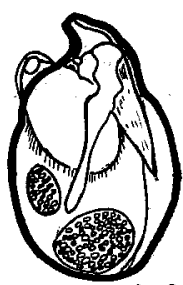

9. 4045

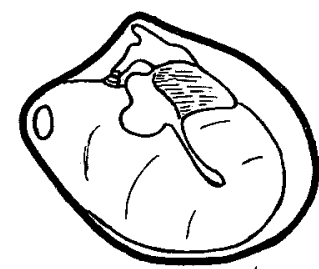

12. 1น:jもり

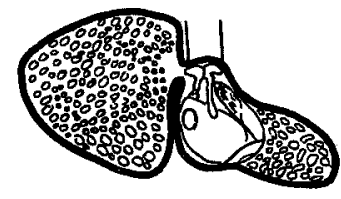

15.にににんざる 
Fig. 3 (2) 中耳腔の北㿟(右倒)

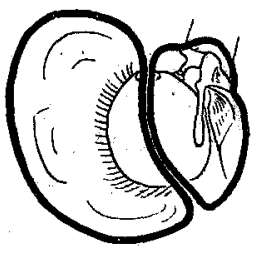

16. $12=$

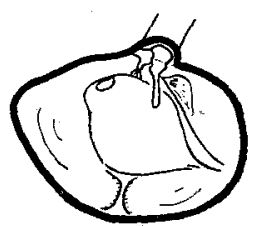

19.か子を

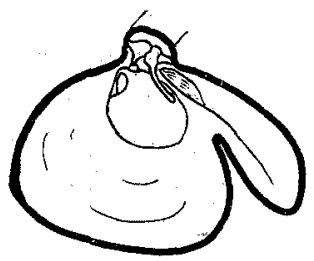

22. $<$ ま

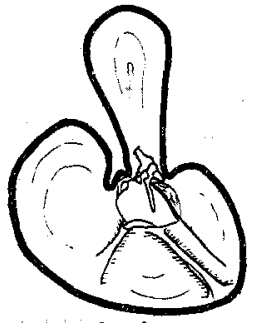

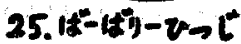

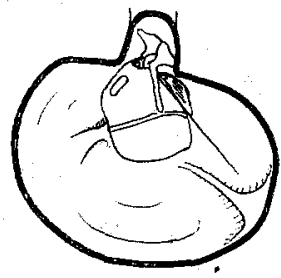

28. Uっ

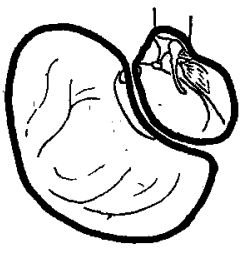

17. $L L$

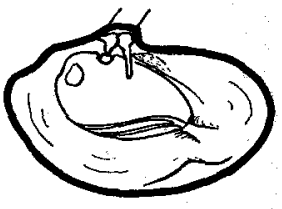

20. おっとせい

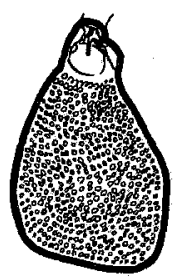

23. is $t$

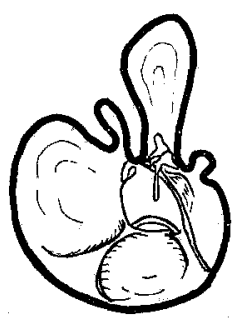

26. かもしか

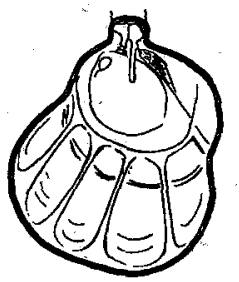

29. $7 ま$

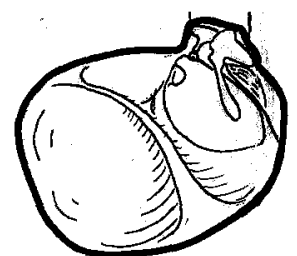

18. 13 ia

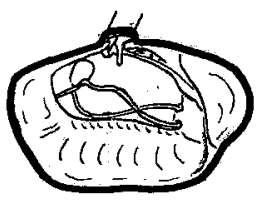

21.あしか

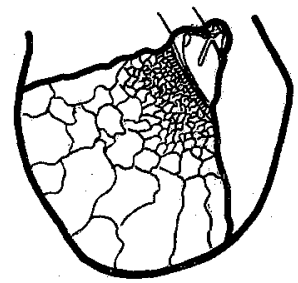

24. $i 2$

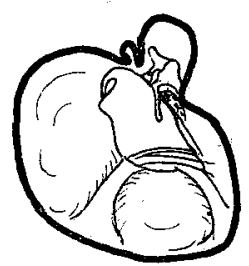

27.

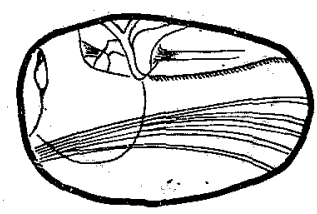

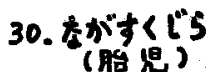


vi.. 中职腃の形態 (Fig. 3)

個々の動物代ついては Fig. 3 て示し，本項では分類 学的に特徽を述べる・

1) 両棲 類

ひきがえる，全用がえるには共に敖膜を底面とした线 い漏斗型の中耳腔があって，そのなかの背尾側に軟骨性 のコルメナが壁沿つて延びて前庭空汇達している：蝸 牛空はない.中耳腔の背尾内方に広くて短い耳管があつ

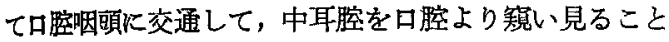
ができる.中耳腔壁は平滑て所々に色素顆粒の疒着が見 光る。

2)爬虫類

有繁目のうち，へび類には中耳腔はなく，とかげ類の やもり，かめれおんに中耳䐋がある・すなわちやもりの 中耳膑位平滑て贱い頭尾方向にのびた半棈円体状を呈 し，尾背側の壁には粘膜に被われた軟骨性のコルメラが あって前庭空に達している・また頭側には広い耳管があ つて口腔と交通しているが，基本形態としては無尾類の 中耳腔によくにている・かめれおんには外耳道と鼓膜が

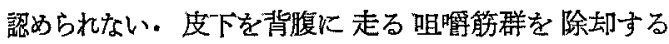
と，方形軟骨前縁に半透明の薄い膜が表れ，その背方は 筋脱に移行し，腹方は上顎骨に附着する．そしてこの内 方に底辺を方形瑱骨に向けた溥い三角形状を呈した中耳 腔がある.その壁は平滑で, 後縁の近くに方形軟骨々前 述の膜（鼓膜?）に分岥して附着する靱帯様のコルメラ があって，背闪方に゙のびている。内壁は得い膜のみて口 院略頭と境され，中耳腔前方にある小孔で交通してい、 ๖.

亀目のいしがめでは鼓朕を除去すると両悽類ににた屚 斗型の中耳凌があるが，さらにその背尾方に楕门形の大 きな副䐦があつて全体としてひようたん型を呈する・鼓 膜輪を形成している軟骨の尾腹側は一部欠除してそこに は䩒帯様の固い綃合組織がある・コルメラはこの部分に 粗に附着しつ〉前庭空にのび，その腹方には中間部は袋 状に拡張しているが，全体としては極めて細い耳管が開 孔している.すつほんては中耳腔は哚い円錐形で壁は平 滑强固である・コルメラはほぶ中央を円錐の頂点に向つ て走り, ニルメシの柄之腹尾方の鼓膜輪欠除部之の閏に 粘腺榆欠除部との間に粘裳が張つて，背尾方向にはいし がめのような大きな副腔はなく，僅かな陌凹を見るに過 ぎない.そして耳管は極度に緗い。

3) 鳥 類

中耳腔は外耳道と同様に目や利の別によつての美異は
極めて少い一般に広範に頭蓋骨に発薏した蜂菓之交通 し，中耳腔の境界は明磪てない，中耳内壁や〉背方を横 に走る中耳内隆起があって鼓室を二分し，この中に血管 を含んている・中耳内隆起の大さは色々で，かるは特に 大くせきせいいんこは細い，中耳隆起の後下方に鼓室 简と称する小さくて测い份凹があつてコルメラの柄が入 り，底に前庭䉥があってその腹側方にある种い骨稜を隔 て〉蝸牛空が存在する・中耳膑闪壁の尾側は概して薄い 骨壁にて被われ蜂亲を透し見るのみであるが，顽側には 背腹に大きな陥凹があつて蜂单に続いている 背部楩凹 ははと，つくみではさらに頭方向と尾方向に分かれる が，かも，せきせいいんこは分離せず，にわとり，しち めんちようては背方向のものが小さい，腹部擦凹はすへ ての鳥類のなかて最も大きい宿凹であるが，はと，つぐ みては耳管方向とシがナ゙方向に分かれて見える・蜂宩は 飛翔する身ては特によく発幸していて，骨稜が粗て細 く，背部楩凹より脳を透見し得るが，にわとり，しちめ んちようては骨棱か琱密て蜂宩は小さい。

4) 呫乳 類

欠蒾目 うさき，りす，ねずみ，もるもつとが属す る・この類は鼓膜輪命っ円形で完全に近く，骨胞は恰円体 形て頭蓋底に照垂し，骨壁はうさぎては厚く，りす (F $1 g$. 4)，ねすみては半透明状火薄い. 胞の内壁は平滑てりす では前下゙部に2つ，うさきては下部に 1 つの低い骨稜か 上下方向に走つているが，ねすみ，もるもつとは平坦て ある・帅はもるもつとては最す強く突出し，りす，ねず みては半球壮をなしうさきは軽く隆起するに過ぎな いむるむつと，ねすみ，りすの岬は極めて薄い骨壁か らなり，内部の蝸牛回転を透見てきるが，うさぎは厚く 硬いりすの砧骨鐙骨は骨壁によつて被われる・上鼓室 は鼓室小骨を容れるたけの大きさの空洞て，前壁も大部 分は骨壁より形成されていて、ンニシプネル氏膜は小さ い上鼓室の他に中耳腔に通ずる空洞が数個䚬妆骨に認 凶られる.

食虫類：もくらの中耳腔は頭尾方向に長い梢円体形 て，们壁には顽側や上方に大きい宿凹，そのや>尾下 万に小さい陌凹があって共に蜂单に続いている・蜂单は 側頭骨，蝶形骨全体によく発達し鳥類ににるか，鳥の如 くに頭蓋全体におよふことはなく，また骨棱のよらな状 態てもない，尾方には岬の隆起が㴜在し，蝸牛回転をよ く透し見られる・上鼓室はかなり梁く棉骨頭，砧骨，鐙 骨を容れンニラプネル膜はない。

翼手類：こうむりは小さかつたためか，内壁は全体 
が岬て骨胞と称さ心゙き部分はなく，中耳腔全体が扁平で ある

霊長類 にほんざる（F1g. 5) はひととよくにた状 態にある・下鼓室は少数個の蜂夈を琵めるのみて小さい が，耳管の周园の蜂亲は良く発奎している.中鼓堂の大 部分は岬て，前下方に頸静脈球の隆起が見られる・上鼓 等より後方に小さい乳様恫を介してよく発幸した乳突蜂

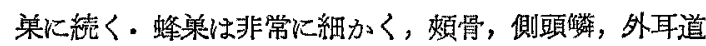
後壁に迄抬がつている。

食肉頻肢脚覀目 ねこ，しし，い内，くま，かわう そが属する・骨胞は大きく滑かな筒円体形てねこ，しし の骨胞懽く，いぬ，かわうそては厚く，くまは側頭骨 中にらずすれている・ねこては後上より前下に鼓朕輪を かこむよらに走るほら完全な隔壁のために中鼓室と骨胞 に分たれ，後上方の小孔て交通寸るが，蝸牛空はこの小 孔にまたがつて骨胞克向くように位置していて，的壁は 岬を二分するよ5に走る・LL（F1g．6）の骨胞子同様 な隔壁て堷されるが，隔壁の上部半分は内壁すなわら珒 と附着しないて細長い裂隙を作る・隔壁は骨胞に向つて 整曲し，中鼓室は扁平な饰円体状て骨胞はそら豆状を呈 する・いぬは隔壁が不完全て上後方ては䄳状てあるに 過ぎない，岬和よび蛸牛究は全く中鼓室にある・くま (F1g 7) は隔壁が更に小さく僅かに耳管の後下方て外， 下壁にあって耳管開口部阤近を区团つているが，内壁は 全く平滑てある・かわうその骨胞は小さく中央下方に骨 稜を見るが，隔壁はなく平滑てある・上鼓室は上上 5 種 に共通して小さく，前壁も殆えど骨壁て形成される。

食肉類缶脚亜目 おつとせい(F1g.8)，あしかては 共に頭尾方向に長い扁平な骨胞があつて, 肢脚類とは逆 に岬の前方に大きく搪からている・骨胞自体は小さく粘

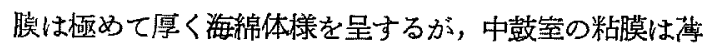
い. 岬は大きく横に長く，かつ蝸牛究が大きいことが目 坝つ・岬の下縁に神経括よひ血管が数条横走し，又下部 には頸静脈王が強く陵起している。

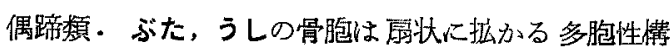
造で䧄も乳突䗋单学見る観がある・うし（F1g.9）の蜂 果は大きく，ふたたは非常に細かい，中鼓室は小さく内壁 は殆んど岬によつて占められる・上敖室は小さく，うし ではンユラフネル氏膜は全くないらし利のば一ばりー ひつし (F1g.10) ひっし゚利のひつし， しか利のかもし か，きよんは同㽷な単胞性の骨胞を有する いずれも大 きく，ひつしは䛅をとり巻くように，他は岬の後方に大 きく拉かり，壁は平滑てある・上鼓室は極めて大きく，
下゙半または下三分の一に鼓室小骨と顔面神経を容れ。 その前壁は巨大なシニラプネル氏膜で構成される・ま 喆膜輪が中耳腔内に大きく突出している。

奇蹢類・うまの中耳腔は異常に小さい. 骨胞は扁 なそら豆形で，鼓膜輪より放射状に走る数条の骨隔壁 よつて不完全に区切られる・隔壁は骨胞前面にのみあ て，骨胞と中豉室の境界は不明瞭である。

鯨類. 胎生 5 力月 (妊娠期間 12 力月) で鼓骨、耳 骨，楻骨の一部に骨化が始つていたが，鼓骨は单一の 胞を形成乙 $39 \mathrm{~cm} \times 25 \mathrm{~cm} \tau$, 礐壁は頭側が厚人尾

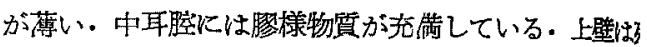
んど耳同骨の岬によつて占められる。䛅に比較するとり 胞の大きさは洒めて小さい(Fig.11).

\section{5. 総括ならびに考按}

\section{1. 外耳道の云十测値}

衈器の比較解剖としては耳介, 鼓涘, 鼓室小骨, ? の計測的研究が多少あるが，外耳道については僅か Freund (1910) がウット合金を用いて8種の哺乳動 についての値をあげているにすぎない. Beyer (1908) はしか，うま，うし，ぶたなど大きい動物の外耳道の， さが非常に細く，しかの外耳道の大さは 40〜6.5mm でうさきより紻いくらいであると述べ Hyrtl (1845) | 翼手, 食虫, 反㗊, 奇蹄, 鯨類の外耳道が狭いと報告] ている.

外耳道入口部が動物の大きさによつて変化する割合 非常に少く，うしとねずみてその比は71に過ぎい しかるに外耳道の長さは頭蓋の大きさや下殂枝の形状 関俰すると Brock (1923), Beyer (1908) が述べて る如く，頭葐の大きさと密接な関連があると思われる これは内耳骨胞および耳小骨の大きさはどの動物でも れ程差がないため，頭蓋が大きくなればそれに比例し 外耳道が長くなること㫴えられる。

外耳道入口部の径と長さの比 (Table 2) を見ると! 上の関係が明らかになる・すなわら頭蓋の大きい動塌 比が大きく，小さい動物程小さい，大きいうし，ふた 外耳道が特に 長くかつ禁曲した 見事なるのであるに! し，ねずみ，もるもつと，りす，こうむりでは耳介は きいけれどあ外耳道自体は極めて短い．しかし外渞 太さはその頭の大きさに比例して变化する必要はない 考えられる。

また同じ種類の動物で頭蓋の大きさが同じくらいの のについてその外耳道を比較する之，長さは殆んと美 ないのに太さには $1 \mathrm{~mm}$ 程度の個体差が常に見られる 
さらにまた成人の外耳道でる日常の臨床において大さに 秏々変化があることに気ずいているが，外耳道の太さま れは長さと大さとの比は外耳道の共脹の点からみて聴覚 にさはどの影響をあたえるすのではないと考えられる。

Wiener and Ross (1946) は外耳道音圧を測定して 外耳道の長さが音波の4分の 1 波長に等しい所几 peak 走生じ，ひとの場合 4000sps 附近であると述べたが， 太さについては何等触れていない. 私はこの理論にした がい，被挨動物の外耳道長より peak となり得る波長を 算出してみた (Table 7).

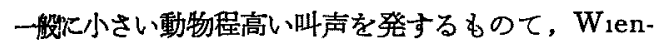
er and Bray (1936) ははとで $1000 \mathrm{cps}$ より $10000 \mathrm{cps}$ 飞执いて蝸中電気反応を認め，Hartrıdge (1945) はこ

Table 7.

\begin{tabular}{|c|c|c|}
\hline 泟 & 物名 & 周波教 (cps) \\
\hline$j$ & ᄂ & 1100 \\
\hline 3 & た & 1600 \\
\hline お & $\oiint^{2}$ & 1800 \\
\hline L & 2 & 1800 \\
\hline ち & $z$ t & 1900 \\
\hline 快一 & エ゙リーひつし & 2200 \\
\hline s & b ᄂ & 2500 \\
\hline 5 & ま & 2800 \\
\hline$v^{v}$ & 8 & 2900 \\
\hline 3 & * & 3000 \\
\hline$u$ & 0 & 3300 \\
\hline$\xi$ & s & 4000 \\
\hline$k 1$ & $\Xi$ & 4100 \\
\hline 3 & U & 4300 \\
\hline$j$ & 巳 & 5000 \\
\hline 2 & めんちょう & 5100 \\
\hline 加 & D $5 ?$ & 5100 \\
\hline 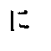 & えさる & 6100 \\
\hline & $\begin{array}{lll}1 & \varepsilon & y\end{array}$ & 7800 \\
\hline & $b z$ & 9900 \\
\hline 泣 & $\varepsilon$ & 11000 \\
\hline s & t & 13000 \\
\hline D & $\ddot{*}$ & 14000 \\
\hline 8 & ぐ & 16000 \\
\hline y & $す$ & 16000 \\
\hline & ぜいいここ & 22000 \\
\hline 3 & れおみ & 25000 \\
\hline$p$ & t $\quad y$ & 47000 \\
\hline & $\begin{array}{lll}5 & b & 1\end{array}$ & 71000 \\
\hline
\end{tabular}

うもりが 30000 ない 70000eps もしくはそれ以上の收 声を哞し，その上限は $98000 \mathrm{cps}$ てあると述へている。 またいぬ、ねこ，ねずみ，もるもつとなどの聴賞の上限 がひとより高く $30000 \mathrm{cps}$ より $50000 \mathrm{cps}$ 程度てある ことを考劣あわせてる，これら動物の聴覚に適した周波 数はひとのそれと違つた独自のものがあると想像され， そしてまな外耳道の長さはそれらの音響をきく点てかな り合目的旳になつていると想像される・

外耳道が存在する動物は诚乳類, 島類と爬虫類の一部 てあるが，爬虫類てはやもりとわにに認められる・おに

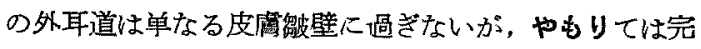
全な外耳道の形をなしている・これはやもりが他の爬虫 類と異り空気中にのみ棲息し，したがつて気尊音を聴く ことが有利であるた外取道が発生したものとすれば， 外耳道は気導音をよりよく埴くために必要なるのと考え ざるを得ない、気導音を衈取するためには非常に䋊細な

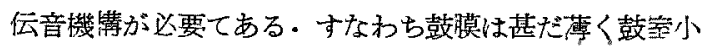
骨文はコル×ラの動きむ微妙であるから，これを外界か ら保濩するにはどうしても外耳道の形を要とするてあ らら・はたさらに，中耳和よび内耳の大きさは生物の盾 類によつてさほどちがいがないが，頭蓋の大きさは大小 いろいろあるのて頭蓋の大きい動物ては体内梁くにいち する傾向にある中耳拉よび内耳に外界の音波を伝える通 路としても不可欠となるてあろう．この二つの理由が聴 覚機構上外耳道の存在する根本的意味ずけてあり，また その形態は前逨の如く和のおの小鳴声よりして恥覚に最 る適した長さともなつていると想像され，聴器の構造の 極めて合理的てあることがこつても理解される。

動物おの持のについて分類学的の特街を篗察すると, 食肉類のうちしし,ねこ，いめくまでは外耳道の长さ と大さとの比が小さいすすな⿰力口外渞が大く炣いこと を示している・食肉類のらち，おつとせい，あしか，氻 わうそては長さと大さの比が大きく外耳道は非常に細長 い形態でこれは水中て盾動する㗘乳䅡に共通な寺色てあ る・Beatty（1932）はあざらしの外耳道が体表に平行し て走り，水中にもぐる時は水圧によって閉ちると述べて いるか゚，あしか，おつとせいてはやはり外耳道は体表に 平行に走つているけれども，これをとり巻く軟骨はか党 つて長く厚く強固てある・したがつて外耳道入口部が閉 镍する可能性はあるとしても，むしろ細長いこと自体が 空気の脱出を防いでいることも考完られる・さらにくじ らの外耳道をみると非常に細長く，なかすくじらで中 間が一部全く開鎖していることは多くの人たの㑇める所 
て西つて，水生䡃物の规い外耳道の最も極端な例と解す ることがてきる.くしらの渎覚については Buchanan, Claudıus (1858) 以来乘多の説がをるか，山田，切替 の見解にある如く骨導を主とすることは定説となつてい る・か3る場合外耳道の必要性は失われ濑次閉塞寸る傾 向がある・水中に生盾寸る動物にとつて気導音上り骨導 音を德くことがより有利と考えられる・Beatty るあし かが水上よりる水中に和いてより锐い聴覚を有すると述 へて招り，これら動物は気導音埴取には不適当な構造を 有すると言えよら。

鳥類の外耳道について Brock (1926), 稩谷 (1934), Beyer（1907）は一般に大く短いが，水鳥類ては狭く， 猛塪類では樑いと言つている・私の埸合も入口部の经は 皆大きく，一見太い感じを与えるようてあるが，長さと 大さの比は诚乳類のそれとは大差なく，つまり体に比し 大きい外耳道を有すると言える。

si. 中耳腔の計測值

同じ㮔類の動物て体の大きさの異るものを比較してみ る上（Table 5，6），いぬ・ねこ共に中耳脸は体重に相 店して変化している・ねこては中㪗室と骨胞が隔壁によ つてよく境され蝸牛空附近の小孔を通じて交通するのみ て両者の体積を別々に測定てきるが，骨胞の体積変動が 著しいのに反し，中鼓室の体積は殆んぞ変らないいい の隔壁は不完全て方るが，骨胞と中鼓室の幅・長さを比 载してほ心゙同棣なことか言える・したがつて中耳胵のう ち，伝音連鎖を蔵する中鼓室は頭蓋の大きさに影響され ず，内耳骨胞の大きさにも差のない点より聴覚にとつて 公理的てあると思われる・これに反し下鼓室または骬胞 は頭蓋の大きさに比例して，またはそれ以上に变化す る・したがつて下鼓室は伝音連鎖に直接影響を拈よぼす ことは考えられない.山下（1932）はひとの鼓室と蜂夈 の体積を計测し，蜂单の大きさは变っても，鼓室の大き さには変作が少いと言い，両者の相関々係がないことを 主張している・また Dahlberg（1940）は蜂采は身長の 增加と共燈育するとし，不破 (1954) は身長・体重と， 下゙田 (1932) は含気する骨の大きさと，土田 (1952) は他 の骨の大きさと蜂巣か相関々係を有するとし， Merkel （1892）は副蕆腔の大きさか頭蓋の大きさに比例して変 化すると主張し，いずれも頭蓋の含気腔が頭蓋の大きさ と関係があることを示している・Diamant (1940) はひ との乳突蜂案は大きさかいろいるてあるのは，遺伝と環 境によって定まると速びたが，私は蜂单の大きさは頭蓋 の大きさによって規定せられ，それに他の因子か泇わっ
て若干の変化を示するのであると考穴る故，含気化抑制 は常に病的であるとする Friedman, Tumarkn (1957) などの見解㵅成するものである。

Table 8. 中耳腔体䖽と豉膜輪面䖽の比

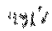

\begin{tabular}{|c|c|c|c|c|}
\hline 動 & 场 & 名 & 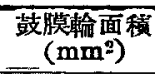 & 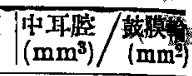 \\
\hline 5 & & L & 52 & 436 \\
\hline ᄂ & & ᄂ & 55 & 240 \\
\hline 3 & U & $\bar{b}$ & 53 & 142 \\
\hline \multicolumn{3}{|c|}{ エ゙ーばリーひっじ } & 24 & 87 \\
\hline מ & \& L & $\phi^{*}$ & 39 & 76 \\
\hline 3 & & $ま$ & 38 & 52 \\
\hline 3 & & $た$ & 35 & 46 \\
\hline$\Xi$ & よ & $\alpha$ & 31 & 37 \\
\hline$j$ & & ま & 48 & 34 \\
\hline$\mho$ & D & $\ddot{L}$ & 37 & 29 \\
\hline 6 & & $n$ & 45 & 27 \\
\hline ¿ & & る & 18 & 26 \\
\hline$n$ & & $こ$ & 41 & 24 \\
\hline お & L & w & 18 & 22 \\
\hline か & b 5 & $\xi$ & 8 & 21 \\
\hline$\$$ & $\supset \varepsilon t$ & $w$ & 18 & 18 \\
\hline Lむ & ＼cjkstart如元与上 & $j$ & 29 & 14 \\
\hline 5 & $\bar{c}$ & 证 & 23 & 12 \\
\hline に & $b \quad \varepsilon$ & り & 25 & 12 \\
\hline は & & $\varepsilon$ & 19 & 12 \\
\hline के & 万 ठ つ & $\varepsilon$ & 21 & 10 \\
\hline す & $\supset \mathbb{I}$ & $\dot{i}$ & 403 & 10 \\
\hline$D$ & $く$ & 两 & 12 & 9 \\
\hline $\boldsymbol{s}^{*}$ & & 8 & 24 & 8. \\
\hline り & & $す$ & 16 & $T$ \\
\hline$p$ & 8 & y] & 3 & 7 \\
\hline क & ぐ & $i$ & 13 & 6 \\
\hline$w$ & ᄂ & 站 & 30 & 5 \\
\hline$n$ & g" & み & 5 & 4 \\
\hline$\zeta$ & しが & 3 & 320 & 3 \\
\hline$\not s$ & & ま & 31 & 06 \\
\hline
\end{tabular}

このような頭蓋と中耳腔の関倸は異種の動物間でるに められる・試みに中耳腔体積と鼓膜輪面積の比をみる (Table 8)，小さい動物程単位面樍あたりの体積は減 していて，骨胞が小さく中鼓室の占める部分が大きく るとを示している・だ゙し両棲類と爬虫類では哣膜に。 して中耳腔の体積が非常に少ないため比る全体に小さ が，これらの中耳腔が原始的て鳥類・哺乳類のそれと 


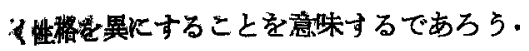

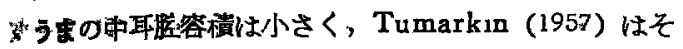
の代りに耳管火大きな空洞があつて中耳胑の代償作用を しているせ述へているが，くまやひつじ類です 1〜3ml であり大きくはない，食肉類でも肢脚類が大きく，䰹

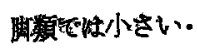

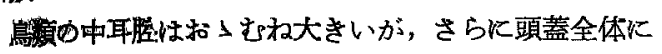

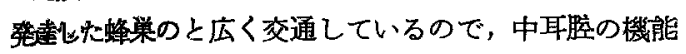
教考光場合るつと大きな体棈を想定する必要がある 5.

爬虫類捛よび両棲類では大きな耳管で口䏸と交通して いるのでこの影掣す考著されれなければならない。

111. 中耳檫と外耳道の体樍の皆 (Table 4)

中耶䋗の体樍は外耳道より常に大きく，その比は種類 k上る美異は明らかでないか゚，特に 2 から4の間にある るのか過半数を占めている・くじらは外耳道の閉鎖のた め大きい比を示すのてあろう・同じ種類の動物を見る と，いぬは3.0〜3.4，ねこ 3.7〜41にあって，かなり一 定した值をとるるのであることが想像てきる・外耳道と 中耳㛬が共に頭蓋の大きさに比例して变化するとすれば 比がー定であることに不思議はないが，特に3を中心に した部分に多いことは，何らか音響学的役割を有するも のではないかと老劣られる。

1v. 外耳道の形態

両㧼類には外取道はない。

觓虫類については Brock (1926) がわにの鼓膜の周 囲炕皮局歔壁が形成され，外耳道の原始的形態がみられ るのみとしているが, Beyer (1907), Burlet (1934)は やもりにも外耳道のあることを記している・やもりでは 非常に稩くから体表と同様の鱗传被われ，単飞体表が陌 入した状態にすぎないもつとも单純な形である・

鳥類の外耳道について Brock (1926), 細谷 (1934) は，一般に不完全で瀻維性の構造を主とし，骨性外耳道

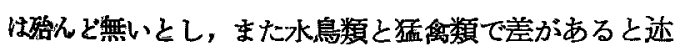
ヘててい.指宿（1937）ははとについて同様な見解を発 表した・私の観察したところでは，鳥類の外耳道は変化 哥多い哺乳類の場合に比し，はるかに単一の形態をと

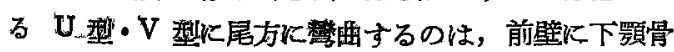
业影突起为あつて膨隆しているためて，前壁には骨性外

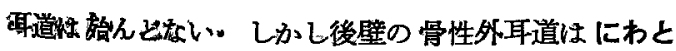
リ、しちんんちよう・はをのように半月状火のみ存在す 西場合すあるが，つぐみ・かも・せきせいいんこの如く
大部分が薄い骨壁によつて支持される埸合もある・晴乳 類と異るむう一つの点は内部が拡がつていることで，こ 礼は鼓膜が外耳道の方向に平行に近いこと〉，鼓膜が笑 出しているための必然の要求であらうと考える。

哺乳類の外耳道の形態汇ついて Van Kampen (1905), Eschweiler (1899), Bondy (1908), Beyer (1908), Freund (1910) が家畜動物について記述して いるが，私は次に 分類別に主な特徴を総括してみる。

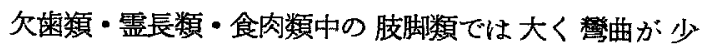
く，軟骨部が大部分を占める・食肉類中の鰭脚類では細 く軟骨部が長いが，輪状軟骨が特に厚く長い、反対汇偶 蹄類では細長く敦曲が著しく，かつ骨部外耳道が大部分 を占める・特にうし・ぶたに著しい. Bondy. Beyer は うし・ぶたに大きなくニラプネル氏膜をみると述べてい るが，ぶたは小さく，うしでは全く存在しない.しかる にしか科のかもしか・きよん，ひつじ利のひつじ，ちし 䅂のばーばりーひつしては非常に大きなンニラブネル氏 膜をみることは面白い.奇蹄類うまの外耳道が短いこと はFreund る䢞へている通りて，骨部が長く，漏斗状を なす・食蝢もぐらの外耳道は外方の広い部分之内方の 狭い部分に分けられ，外方部は耳介に相当すると思われ るがここれは地中生活に適した構造と言えよう・くじら の外耳道については山田(致)が，まつこうくし゚らては䄄 長いが完全に体表まで続いているが，ながすくじらては 体表の外方部と中耳に淁妾する内方部の間は閉鎖し結合 組織に拉きかわつていると報告している・私の標本は胎 生 5 力月（妊娠 12 力月）て，まだ外方部はなく，内方 部が铅筆キャッフ状に存在していた・切替はくじらの音 感覚が純骨尊・骨鼓室伝導および塤室膑の共鳴より成立 すると説明したか，いずれにせよ外耳道不用のため極度 に退化した状態て，水生哺乳類の最も極端な形てあり， したがつて二次的な退化てあると言える。

v. 中耳㓐の形態

1) 両楱 類

有尾類には耳小骨のみがあつて中耳腔はないが，無尾 類に始めて善膜と中耳腔をみることかてきる・がまなど の中耳については Retzius(1881), Beyer (1909), Bu rlet (1934) の記載がある. Tumark1n (1957) はその 特徽として耳小愲か一個のみて，耳内筋・耳管・副朕が 久除すると述べた・しかし中耳腔の上後内方に広く口腔 と通ずる通路以は若干の距離があつて， Burlet のよう に太い耳管と形容するのが適切なようであるし，また m. opercular1s は鼓膜を内方に索引する働があるから， 
耳内筋と同像と考えてよいであろう。

中耳形態からみると有尾類は全く骨遒のみを聴くもの と思かれるが，無尾類もまた鼓膜が非常に厚く微妙な気 㮍音聴取には不適と思われる・Burlet は方形軟骨から 淋巴腔值接圧を括よぼし得る構造から骨尊の主たるこ とを主張し，また Yerkes (1905) はかえるが 50〜 $10000 \mathrm{cps}$ の周波数て反応するが，鼓腺とコルメラを除 去してる変化せず，聴神経を甽断すると反忘しなくなる と述べている・しかし鼓朕括よびェルッラの存在は，僅 かでも気對音聅取ができ得ることを示すものてあるが， 鼓膜があるためにはまた中耳胵も不可欠て漏斗型は中耳 凌の最小限の体積すなから最も原始的な形と見なすこと がてきる・鼓膜輪の面渍と中耳腔体倩の比をとつた培合 (Table 7), 背椎動物中最も小さい值をとるのはこのこ 之を意味するものてある。

2)爬虫類

爬蝜の中耳は最も多彩な形態を呈する・ヘびは中 耳腔はなくニルメラが方形骨に附着し，基本形態は両梙 頪の有尾類㳊等しいVVersluys 抌よび Beyer はとか

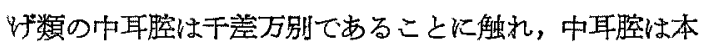
質的なむのでなく㸶頭の一陷凹にすぎず，またコルメラ は絬脱に被われると述へ，またかめれおんについては鼓 脱が退化消失し，コルメラは方形骨に附着して招り， 咽頭との交通は粘朕敭壁て狭まっていると述べている。

やもりの中耳腔は両慎類の無尾類に似ているが，中耳 腔は棈円体状にふくらんで大きくなり，かつ耳管開口は 頭側に移動する・そして鼓膜・コルッラが鳥のように瀻 勫になること，外耳道があることは気導音聴取能力がか なり良いことを想像させるが，これはやありの生活が他 の爬虫類とらがつて空気中に限られる生佸環境にうまく 適応ている事実である・したがつてやすりの德器は両 接類から鳥類に一步近ずいた状態とも言兄よう。

同じとかげ類に属するかめれおんには外耳道も鼓脂る

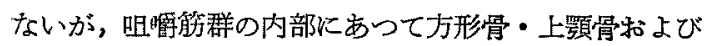
筋膜の間に 張つた半透明の膜にはコルメラの枝が附着 し，かつ Beyer もとかげ類の鼓膜は方形・上靧筋の間 に張っていると速べているが，これは鼓膜の退化したも のと考えられよう・退化したと考学る理由は中耳腔が存 在するからてあつて，この中耳腔は全く無意味な存在て ある・したがつてかめれおんは骨導聴取動物てあり，ゃ もりとへびの中間型とみることができる。

かめの中耳腔について Burlet は方形骨からなり漏斗 状で後下端に甽れ込みがあること、コルメラとこの切れ
込及の間に絬膜貱壁があり，中耳腔は不完全に上部と下 部に分けられ，下部に細い耳管が開くと述へている。彼

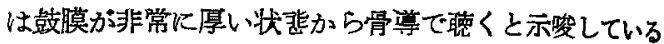
が，Adrıan 等 (1938) Kよると，かか心 50 300cps

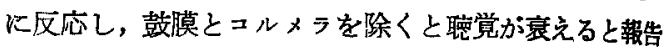

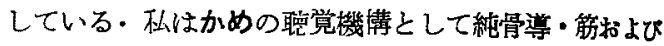
骨よりコルメラを経る骨裁室伝導・気導の三者を教慮才 るが，鼓膜和よびュルメラの可動性の比較的良いいしかi めですへてての可能性があり，また鼓慔が皮下に5もれて 厚く硬くコルメラの可動性も少いすつぼで瑐二者特 に純骨導が重要な役をしていると考劣る・そして多少と も気導を聴いていると考党られるいしがめでは, 耳管そ のものは細長いがその代りに大きな副腔があること忖興 味深い点である。

また鼓膜輪の面㥽と中耳腔体積の比は (Table 7)， 网槙類程てはないが小さく，い主だ中耳腔の発達の悪い 状態を示している。

3) 鳥 類

Hasse, Retzius, Beyer, Denker, Brock, Burlet, 指 宿の別截がみられるが，Hasse によれば鼓室に続く副 胿は，中耳内隆起の背方より，頭側と尾側発達する 2 小孔と，䧗方より耳管へ通ずるるの，同しくくラゲナ周团

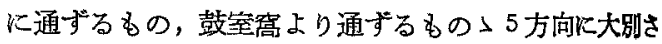
れると言らが，これ該当するのははと・つぐみであっ て，にわとり・しちめんちようては背部樎凹のらちで尾 側のものは非常に小さく，かあ・せきせいいんこではこ

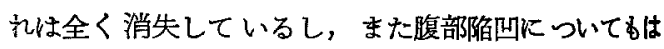
と・つぐみ以外は耳管方向とラゲナ方向と分けるととは 因難である・頭蓋内蜂单の発育はや小程度の羑があう て，このはずくては下顎骨に迄およらと言われるが，一 般に飛ふ鳥では䗦巣が粗く，骨稜は細いのは環境による 变化てあろう.

4) 哺乳煩

哺乳類の中耳については Hagenbach, Hallmann, Pol, Eschweller, Chauveau, Beyer, Butschl, 池田, Wittmaack, Brock, Burlet, Echert-Móbıus, Ardouın, Wolff, Parrington, Lambert, 柴田，栗田，Secondı，Tumarkın など多数の報告があるので，私忙骨 胞の形態と分類学的関係を総括してみる・伝音連鎖们つ いては別に報告する予定である。

動物の分類学上の位置之副腔の形態とは，大部分飞お。 いて統一された関係を見るが，一部には㻴境によってか なりの違いを示すことむある。 


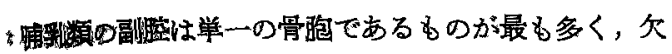

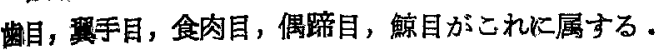

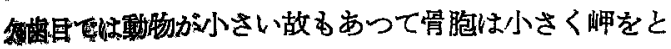

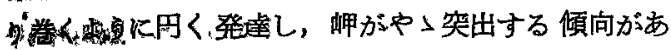

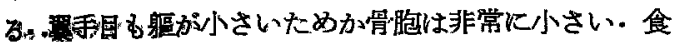

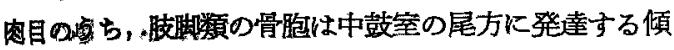

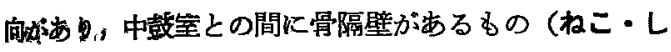
し)とないるの (くま・かわうそ) 於よびその中間型の い四三不分けられる・食肉目のうら，鯺脚類の骨胞 はむしてろ岬の前方に大きく発奎するが，小さく横に長 いッこの類の骨胞の秥朕は海綿体栐に肥厚していて，

Beatty 怯この粘膜に着目乙，動物が潜水する時水任か 上昇するにつれてこの粘掉に血源が充満し，中耳胵を狭 くして压の平衡を保つと説明したが，この構造が䱛脚類 の沓充ることから興味ある考え方てある・Fraser \&

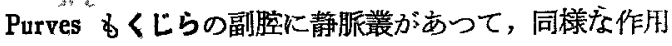
家持つことを報告している・偶蹄目のうち，ばーばり一 ひつじ・ひつじ・かむしか・きよんでは䛅の背方に発迲 する大きく細長い骨胞があって隔壁は全くない。この類 の特徽は上鼓室が大きいことてある・ばーばりーひつし 恃分類学上うし利に属するが，外取道・上唼窒・鼓室小 骨および骨胞の形態は全くしか利と同じである・したが ってらし稍としか利の移行型であるうがははーばりひつ しがフフリカ地方の岩山地帯にいて，かもしかと同㥞の 生活浢境にあること〉一致している・鯨目では管胞は水 凄哺䧽類共通の現象て骨盷が小さく，胎生 5 カ月で 39 $\mathrm{cm} \times 2.5 \mathrm{~cm}$, 成体です $12 \mathrm{~cm} \times 6 \mathrm{~cm}$ にすぎない，山田 （致）火よるば中耳骨胞に相当するのは鼓骨之言われ， 上方陌凹し薄い幅広い短茎で上方の内耳を容れる耳周 骨と結合し，この両骨の間に鼓室が存在する・鼓室の頭 賏仕翼状简があり前端に耳管が開口ふると言う・基本 的形態恃陸捿哺乳類之全く同嵄であつて，明かに陸桻上 り水椳火なるにつれて，二㐸的に变化したるのと解立る ことができる。

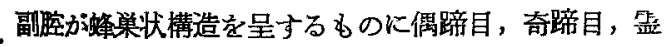
镸目，食虫目がある・このうち偶蹄目と奇蹄目は骨胞に 蝶巣がみられる・うしでは最る奥型的で中心部は細か く，周辺部程大きい蜂单が厥形にあって，あたかるよく

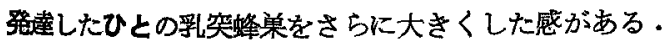
ふたで蜂菓ははるか絧かく，周辺部にも大きい蜂单 はない.Tumarkin に上ればいのしし・かは・らくた 同様な多胞性構造を示すと言う・Beyer，Tumarkın はうまとばくの骨胞が非常に小さく，耳管に膨大部があ
つて胃胞の代償作用を営むであろらと麻べているが，碳 かに大きさはくまやいぬくらい炕すぎない、站膜輪より 放射状几走る数枚の骨壁によつて区切られ，槅壁は骨胞 の側腹面にあって骨胞と中鼓室の境界は不明膫てあり， 多胞性と単胞性の中間型とみることができよう。

需長目の中耳腔について Tumarkın は下等なるので は単胞性の骨胞があるが，広番類ては骨胞と共に錐体括 よび孚突蜂栄が出現し，高等なちんばんじ一・おらんう 一たん・てながざる・ごりらては骨胞は殆んど消失して 蜼体扣よび乳突蜂亲が大きくなり，脚にごりらてはよく 発奎していると述べている－Brock は雪長類には骨胞 は殆んどないと，また Wolff は Macaccus には乳樣 突起がないと記している・私のにほんざるは狭䙹類猿下! に属し，一見してひとと良く似た状態てあるが，耳管周 㜀の䗋单が著明に発幸している。

乳突蜂菓の発羍する理由について Tumarkin は無暨 室的役割と，起立步行するための乳録突起の補强を老え ているが，こ机はうし・ぶたの㻛合も恐らく同柈である ら・くしらの骨胞に時々骨折がみられると言らが，これ は単胞性の骨胞が决して丈夫なものてないこをを意味 し，したがつてうし・ぶたなどの大きい骨胞は蜂单によ つて補強されていると考克られる・うまの骨胞は小さい ためその必要はないてあろら・

食虫目については Hyrtl, Beyer, 池田, 後藤, Tumarkın らの報告があるが，後藤は頭蓋骨基底の蜂巣が中 耳の内側括よび前側に開口し，その内耳をとりかこむ状 態は伝音菱置以外上り人る音響の逶断作用を示すと説明 している・もぐらには骨胞はなく，蜂单が内耳をかこむ ように発幸している点は全く独特てあり，池田の言う如 く，その地中生活の必要上，舟響室的役割を果するのと 想像される。

\section{v1. 副㻠の意戴}

霄烰頪の中鼓室は前麻の如く形態の变化が少く，かつ 頭蓋の大きさにあまり影響されず，伝音連敛にとつて必 要にして充分な最少の大きさのみを保持するものてあ

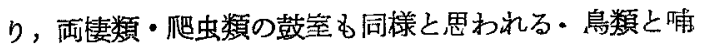
乳颖には多くの副腔が存在し，何等かの機能を宮むこと が想像される・Tumarkın は副腔の意義について resonance, reception, insullation. reservoir action, acoustic dissipation の可能性を論じ，動物によつて主 な役割は異なるとした・

单胞性の骨胞烘㕷效果があることは幾分老えられる 


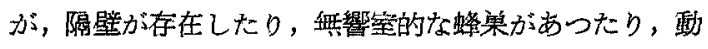
物の成長炕伴つて大きさか变ること，こうもりなどは骨 胞が殆んどなくなることなどは共㗇が殆んど問題になら ないことを示するのである・

町替は中耳腔の音響特性についての模型実験て，副腔 の存在は低音に抽いて気窒の音響インピーダンスを低下 せしめ，鼓臊振動の抑制を少くし，乙たがつて低音の場 合中耳胵の全容㥽が鼓膜に影響を枋よぼし，高音ては鼓 室のみが作用すると述へた・私はこって哺乳類の中耳腔 之鳴声を比較する時，極めて合理的てあると感ずる。す なわち鳴声の低いうし・ぶた・しし・くまなどの中耳璄 が広く，鳴声の高い小動物程中耳胵は絶対的のみならず 相対的にも小さくなる・綮胞の殆んどないこうもりが 30000 扣よひ. 98000 cps の超音波を発して通信扣よび索 物を行ならのは Hartridge の説に述へられている・う まの鳴声む比較的高い.Wever などが実験した骨胞の

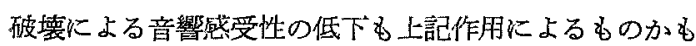
しれないが，共鳴についても否定てきない。

Boenninghaus, 恩地, Pullen 蜂菒が防音作用を有 すると主張し，Macdonald は蜂单の音の吸収作用によ つて, 鼓膜の振動に際し鼓膜後部に発生する音波を吸収 すると述へ，また他田，後藤はもぐらの蜂单に音響造断 作用があるとした，Tumarkin はもるもつとの螎牛か 骨胞内に乫出しているのは内耳の音響的滆離であろう か，この作用は少いと速心，Barany は陸椿動物ては伝 音連鎖がよく登虚しているから組織伝尊は非常に少いて あろらと想像している・島の上うに激しい運動をするも のにとつて，内耳を蜂宩て鄵離するのは有不なようてあ るか，飛ふ島の䗋菓が飛らことのてきないにわとり・し らめんちようの䗋单よりはるかに粗らく骨稜が細いこと はもしろ逆の效果となるてあ万う・また哺乳類の骨胞の 多くか，内耳との位置関係か嗐接でいことも隔㲓作用 か重要てないことを示すと考觉る。

巾耳腔と外気の圧の平衡は常に聴覚にとつて大切てあ り，中耳腔または外気の急激な圧变動がある場合，副 朘は压变化を少くするように㗢くことが些えられる。 Tumarkin は含気化抑制のあるものに圧变化による外 傷か起り易く，したがつて副腔は“aur cushion”てあ るとし，中耳䐘の小さいうま・こうもりの耳管に大きな 袋があるのはこの作用を代賞するためと解釈している。 鳥類の環境汇压変化が大きいこと〉䗋单の発育とは剧連 するように思われるか，やはり外界の圧が変る水捿哺乳 類て逆に骨胞が小さいことや，小動物て相対的にも骨胞
が小さいことは相反する事実であつて，すべてに該当す るわけてない。

Tumark1n は同様な作用で副舷がない，場合教膜振動 による中耳内の圧力変化が大きくなるから，鼓膜・蛽 空啅の動きに抑制または歪ができると主張している・し たがつて副䐋は無暨室的役割を果す上言ら・骨胞の大き い場合このことは洘虑され得るであららが，やはり小動 物に执いては不合理と考えざるを得ない。

仏はさらに頭蓋重量の軽減と言う意義について考充た い. Merkel は副鼻䐩の大きさが頭蓋の大きさと平行関 係があるとしたが，中耳望体樍の項で述へた如く，頍蓋 の空洞がみな頭蓋の大きさと平行関倸があることは，頍 蓋をできるだけ軽量化する働を示すものであるう・鳥類 の蜂巣の発育が飛ら鳥に最も著しいことはこの要求借 くと考劣るのが最も妥当である・ぞう・うし・ふた・う まの頭蓋骨に多数の空洞が認められることも，骨胞の状 態と一致している・だ゙うし・ぶたの骨胞の䗋亲”゙头き さが，頭蓋の空洞とは全く大きさの異つたものであり， また骨胞の多くが頭蓋底に懸垂する位置にあつて肪の附 着もないことは，副胵が单なる軽量化のみでなく，上記 の種々の作用を兼ねているものと考皃ることがでさる。

\section{6. 結 論}

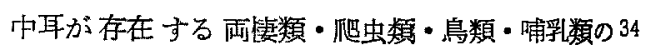
陲について，外耳道と中耳媵の計測を行い，かつその形 態を観察して次の結論を得た。

1. 外耳道の長さは頭蓋の大きさに心して比例的に変 化するが，太さの変化は少く，長さと太さの比は大きい 動物程大となる。

2. 外耳道は気遵音衈取に際し, 形態的に不可欠な のてあるが，一面長さによって定をる外耳道の音響特性 は各種動物の鳴声の特性によく適合していると考えられ る.

3. 外耳道と中耳凌の体積の比は動物の喠によって一 定した值を有し，特に2〜4の間に多い。

4. 鳥類の外耳道の形態は哺乳類と晎り, 単純である. 内端は唃乳類と逆に常に抎大している.外取道後壁不は かなり長い骨部を認めるものもある。

5. 水楼踭乳類の外耳道注特似細長くなる傾向があり， くじらの外耳道が閉鎖しているのはこの極端な 例であ る.

6 食肉類预よび島類の外耳道は太く体債も大きい.

7. 同種動物について，中耳腔のなかで成長に伴って 大きさの变るのは骨胞すなわち副腔であつて，伝摬直 


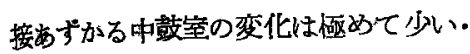

8. 異種動物认ついても同じで，小さい動物程这膜輪 に対する中耳腔の体積の比率は小さい

9. 雨悽類の中耳腔の形態は最も原始的で鼓膜とコル ネラが存在するための最小限度の大きさに過ぎず，した

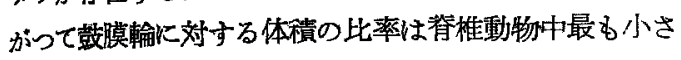
いが，爬蝢に至ると徐々に大きくなり，かぬに至つて 㔀臸が發生する・

10. 鳥類の中耳腔は互に類似するが，蜂栄群の形態括 よび蜂巣の大きさに若干の羊劣ある。

11. 哺孚類の副䶼は単胞性の骨胞と多胞性䗋巣状を呈 するむのに分けられ，前者には隔壁の有無があり，後者 に江蜂巣が骨胞・乳樣突起・頭蓋骨基底にそれぞれ認め られるものがあるこどを分類学的に述べた。

12. 副腔の存在意義について6つの可能性をあけ゚，音 響インビーダンスの低下，頭蓋の軽量化，中耳腔内圧力 の変動の”緩衡作用が重要であるらとした・

13. 中耳腔の形態は分類学的に久て統一性があるが， 時には㻴境店じて変化することをばーばりーひつじの 例で説明した。

14. 頭蓋の中の含気腔は頭蓋の大きさに 相応して変化 する傎向があり，含気腔の大きさは常に顽蓝の大きさと 対照せかばならぬことを述べた。

\section{7. 文献}

1) Ardouin, P.: Anatomie comparée de la chaine des osselets de l'ouie dans la serie des mammiféres. Rev. de Laryng., etc.. 56: $427 \sim 489,1935$. 2) Beatty, R.T : Hearing in man and animals. London, 1932. 3) Beyer, H.: Studien über den sog.

Schalleitungsapparat bet den Wirbeltieren und Betrachtung uber die Funktion der Schneckenffenster. Arch. f. Ohren, Nasen-u. Kehlkopfhellk., $71: 258 \sim 292,1907 ; 72: 278 \sim 304,1907 ; 75 \quad 243 \sim$ 259, 1908; 77:77 105, 1908; 78:14 34, 1909. 4) Beyer, $H \cdot{ }^{\cdot}$ Übersicht über die Fortschnritte auf dem Gebiet der vergleichende Anatomie des Mittelohres. Beitr. z. Anat. Physiol. Pathol. u. Therapie d. Ohres, d. Nase u. d. Halses, 1: 152 182, 1908.

5) Brock, W.: Phylogenese und vergleichende Anatomie des Gehororgans. Handbuch der Hals-Nas. en. Ohrenheilkunde von Denker und Kahler, Gehörorgan 1: 41 55, 1926. 6) von Buddenbrock,
W.: Grundriss der vergleichenden Physiologie. Berlin, 1937. 7) Burlet, H.M.: Vergleichende Anatomie des stato-akustischen Organs, Handbuch der vergleichende Anatomie der Wirbeltiere von Bolk, Göppert, Kallius u. Lubosch, 2Bd., 2Hàlfte: 1381 1444, 1934. 8) Bütschli, O.: Vorlesungen über vergleichende Anatomie. Berlin, 1920. 9) Chánveu, C.: Sur quelques points D'anatomie comparée de l'oreille moyenne et l'oreille externe. Arch. internat. de Laryngol. etc., 18: 515 525, 857 873, 1904; 19: 139 144, 1905 . 10) Diamant, M.: Otıtis and pneumatisation of the mastoid bone. Acta Otol. Suppl., 41: I 149, 1940. 11) Eschert-Möbius.: Vergleichend anatomische Untersuchungen und Pneumatisationslehle. Acta Otol., 26:115 127, 1938. 12) Eschweiler, R.: Zur vergleichende Anatomie der Muskeeln und der Topographie des Mittelohres verschiedener Saugetiere. Arch. f. Mikroskop. Anatomie, 53: 13) Freund, $L$ : Morphologie des äusseren Gehorganges der Sáugetiere. Passows Beitr., 3: 1 34,

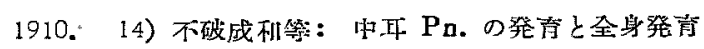

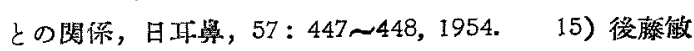

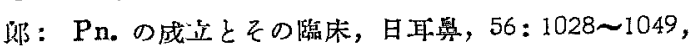
1953. 16) 後藤松一：モグラ中耳の形態学的研栄襧 遊, 日耳莮, 33: 966 972, 1928. 17) Hallman, E.: $D_{1}$ vergleichende Osteologie des Schläfenbein.

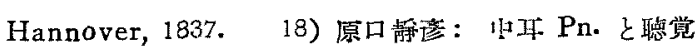
との関你. 19) Hartridge, H.: Acoustic controll in bat. Nature, 156:692 693, 1945.20 ) 细谷雄

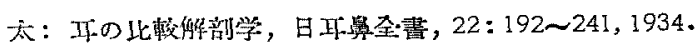

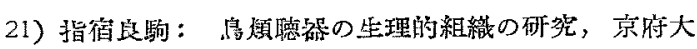
堆点，23：349〜432，1938. 22）池田昌克：モグラ聴

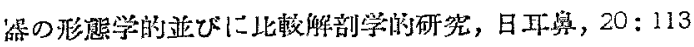

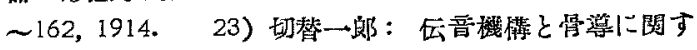

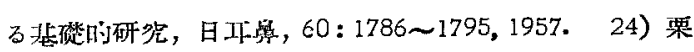

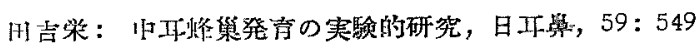
556, 1956 . 25) Macdonald, P.G.: Functioning of the air cell system of the mastoid process in audition. Arch. of Otol., 49: 447 462, 1949.

25) Parrington, F.R.: Remarks on a theory of the evolution of the tetrapode middle ear. Jour. of Laryng. and Otol, 63: 580 595, 1949. 
Prosser, C.L.: Comparative animal physiology. Phyladelphia, 1950, 28) Retzius, G.: Das Gehörorgan der Wirbeltiere. Stockholm, 1881.

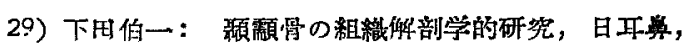
38: 209 234, 1932. 30) $S y k, I .: \quad$ Zur Kenntnis der Morphogenese der mittleren und äusseren Gehorspheren bei Amniota. Acta Otol., 1: 532 538, 1918. 31) Tumarkin, $A:$ On the nature and vicissitudes of the accessory air spaces of the middle ear. Jour. of Laryng. and Otol., $71: 65 \sim 99$,

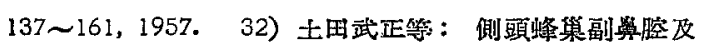

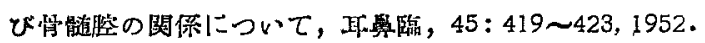
33) Wever, E.G. Lawirence, M. and Smith, K.R.; The middle ear in sound conduction. Arch. of Otol., 48: 19 35, 1843 . 34) Wever, E.G. and Lawrence, M.: Physiological acoustics. Princeton, 1954. 35) Wever, E.G. and Bray, C.W.: Electric response of inner ear, Jour. of Comp. Physiol., 22: 353 363, 1936. 36) Wiener, F.M. and Ross, D.A.: The pressure distribution in the auditory canal in a progressive sound field. Jour. of Acoust. Soc. Amer., $18: 401 \sim 408,1946$, 37) Wittmaack, K.: Über die normale und die pathologische Pneumatisation des Schläfenbeins. Jena, 1918. 38) Wolff, D.: Histopathology of the ear, nose and throat. Baltimore, 1947. 39) Yamashita. K.: Uber die

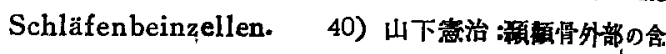

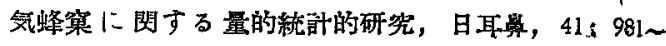
$1001,1935$.

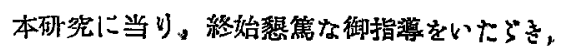

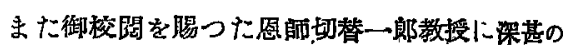
謝意を装し，併せて多大の御援助ならびに御教 薄を頂いた本学䐪剖学教室藤田恒太郎教授，当

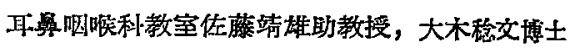
に深謝する・

本論文の要旨は日本耳鼻咽喉科学会東京地方 会第 349 回例会に゙おいて発表した。

（原秙到着＝昭和 34.5.29 日一急載） 


\section{福田論文付図（I）}

Fig. 1. ししの外壬道と鼓膜

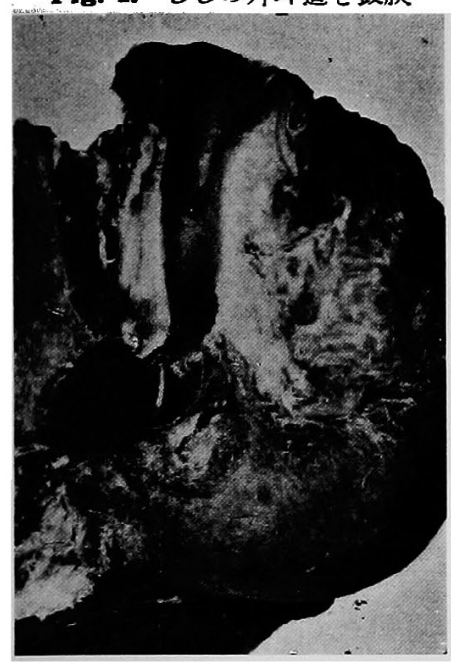

Fig. 2. ふたの外耳道

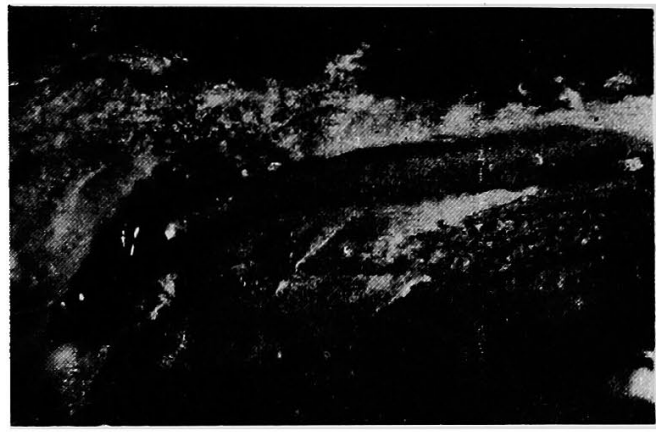

Fig. 4. りすの中目:

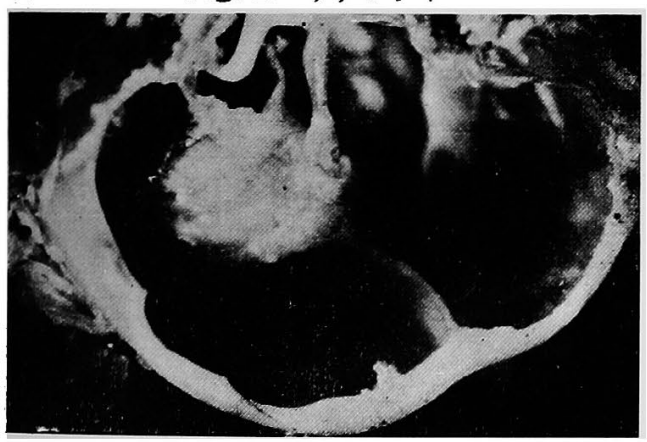

Fig. 6. ᄂしのツษ:

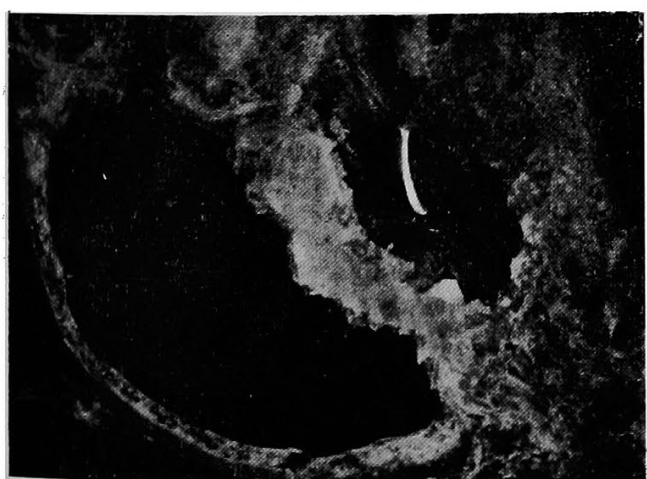

Fig. 5. に゙ほえざるの国

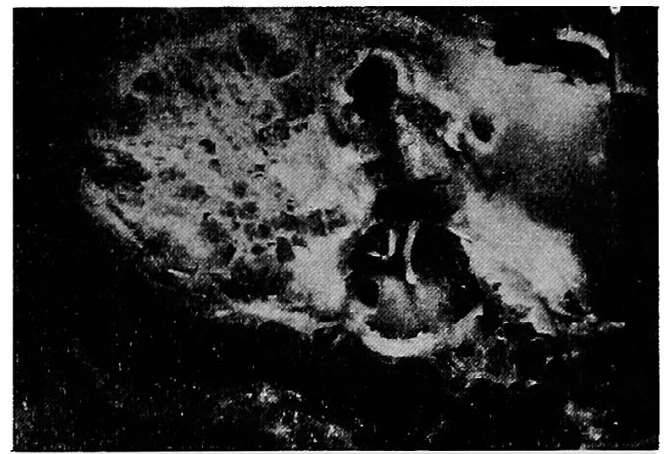

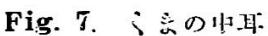

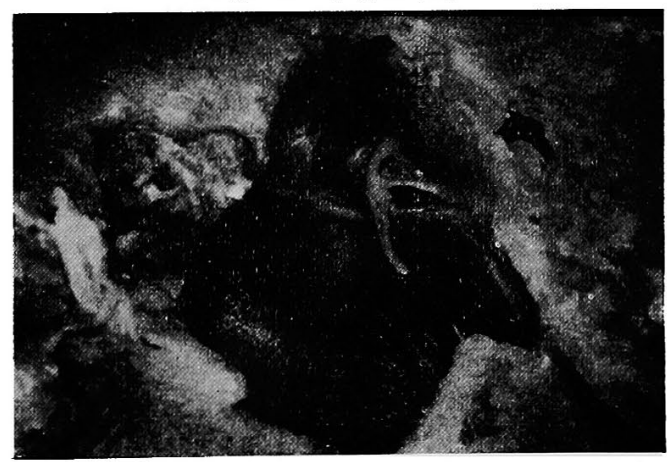




\section{福田論文付図（II)}

Fig. 8. おつとさいの中耳

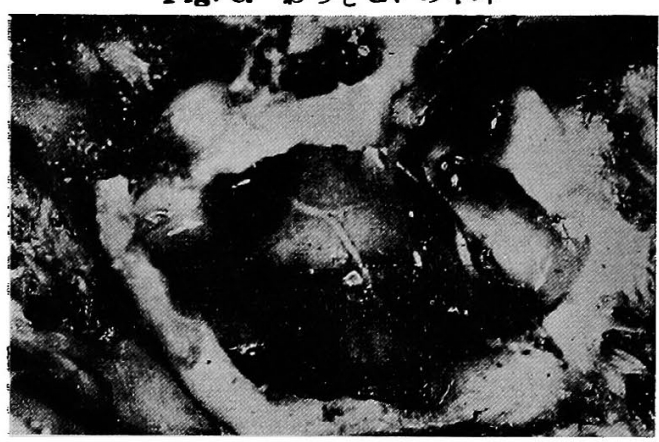

Fig. 9. うしの中.耳

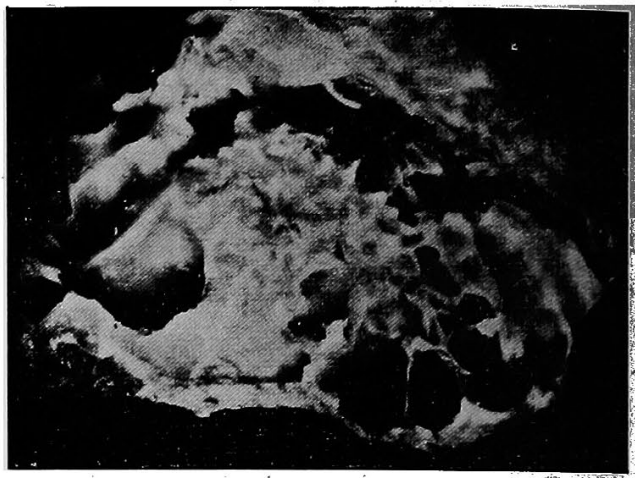

Fig 11.ながすくしら（胎兒）の中耳

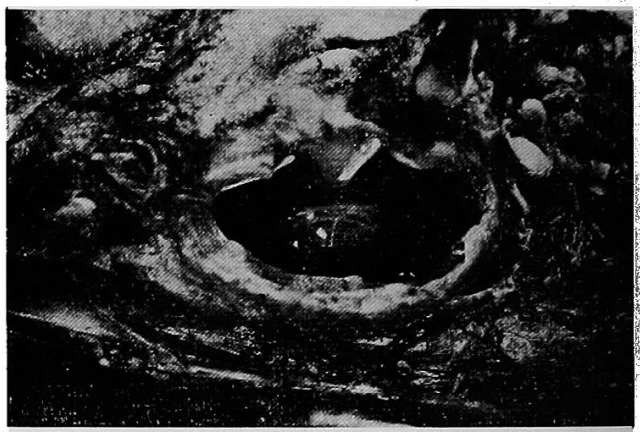

Fig. 10.ばーばりーひつしのゅ耳-

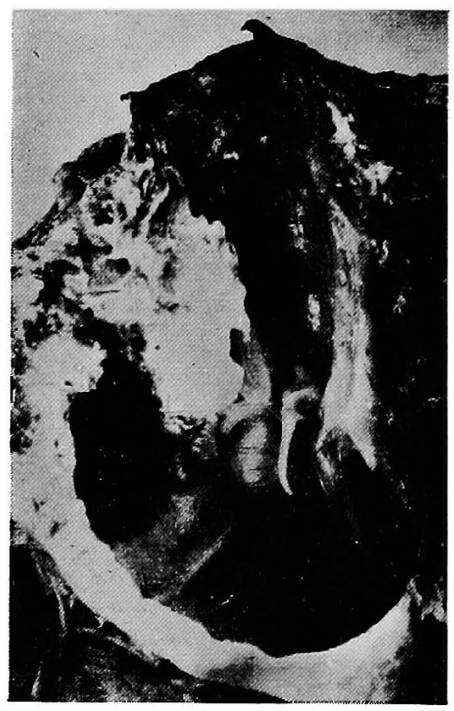

